\title{
Somogy megye római kori temetői
}

\author{
NÉMETH PÉTER GERGELY
}

Rippl-Rónai Megyei Hatókörü Városi Múzeum

H-7400 Kaposvár, Fő u. 10., peter@smmi.hu

Németh, P. G.: Roman Cemeteries in County Somogy. Abstract: This paper continues the article on Roman Age barrows published in the previous Yearbook. Beside Roman cemeteries covered in earlier literature, it presents more recently found burials.

\section{Keywords: Roman Age, Cemetery}

A tanulmány a korábbi évkönyvben megjelent római kori, halomsíros temetkezések tanulmány folytatása. Bemutatja a megye területéről előkerült római kori sírokat. $A$ korábbi szakirodalomban közölt római temetők leleteinek ismertetése mellett, az újabban elökerült római temetkezéseket mutatja be. A rajzokat Ambrus Edit készítette. A térkép, a sírrajzok szerkesztése, és az I. tábla 1., 3. és 7. rajz Nyári Zsolt munkája. A fotókat Balla Krisztián készítette. Az érméket Torbágyi Melinda határozta meg. A római kori temetkezésekből előkerült kisszámú, töredékes és hiányos csontmaradvány embertani vizsgálatát Merczi Mónika végezte el. Az angol fordítást Csizmadia Gábor készítette. Munkájukat ezúton is köszönöm.

\section{Alsóbogát - Csollányosi-erdő}

Halomsíros temető. ${ }^{1}$

\section{Andocs - Nagytoldi-puszta}

1926-ban szarkofág került elő, melynek fedőlapja hiányzott. Mellékletekről nincs említés. A szarkofág Nagytoldipusztán maradt. ${ }^{2}$ A közelmúltban még fellelhető volt, később eltűnt. ${ }^{3}$

\section{Attala}

1925-ben mécses került be a kaposvári múzeumba, az egykor Somogy, ma Tolna megyéhez tartozó Attaláról. ${ }^{4}$ 1948-ban négy téglasír került elő. ${ }^{5}$ Leletekről nincs említés, így a korábban előkerült mécsesről nem tudjuk, hogy sírból származott-e. ${ }^{6}$

\section{Babócsa - Merész-szőlők}

Római téglasírokról és villamaradványokról történik említés, konkrét leletanyag nem ismert. ${ }^{7}$

1 Csizmadia-Németh, 2016. 124-126. KÖH 19776. lelöhely.

2 Rippl-Rónai Múzeum Adattára (továbbiakban RRM A.) 1/1/2. és Draveczky-Sági-Takáts 1964, 7. KÖH 22918. lelöhely.

3 Bognár Zoltán helytörténész (Kapoly) tájékoztatását ezúton is köszönöm.

4 Kocztur 1964, 6. és RRM A., tárgykarton.

5 Kocztur uo.

6 Bakay Kornél véleménye szerint a mécses nem Attalán, hanem Dombóvár-Kapospula-Alsóhetény lelöhelyen került elő. Bakay 1975, 30.

7 Magyar 1987, 244.

\section{Balatonberény - Belterület}

Börzsönyi Gyula telkén téglasír került elő, benne 4. századi érme és füleskorsó volt. ${ }^{8}$ A leletek Börzsönyi Gyula talajdonnában maradtak. A Fazekas villánál 4. századi téglasír leletmentését végezte el Sági Károly. ${ }^{9}$ A két sír egy temetőhöz tartozott. ${ }^{10}$ 1997-ben újabb téglasír került elő, amelyet szétdúltak. ${ }^{11} \mathrm{Ez}$ a harmadik sír is ehhez a temetőhöz tartozott. ${ }^{12}$

\section{Balatonlelle - Rádpuszta-Agyagbánya}

1973-ban Magyar Kálmán egy római téglasír szétdúlását konstatálta. $\mathrm{A}$ sír a régi $\mathrm{M7}$-es úttól délre, $\mathrm{kb}$. $3,5 \mathrm{~km}$-re, a rádpusztai bekötőút nyugati oldalán lévő agyagbánya művelése során semmisült meg, mélysége 150-200 cm lehetett. ${ }^{13}$ 1974-ben, az agyagbánya környékén végzett földmunka során, melléklet nélküli, zsugorított csontvázas sír, valamint egy római sír került elő. Az ÉK-DNy tájolású, mintegy $80 \mathrm{~cm}$ mély, csontvázas római sír leleteit összegyüjtötték, és a kaposvári múzeumnak átadták. A leletmentés során újabb sír nem került elő. ${ }^{14} A$ még ebben az évben elvégzett helyszínelés során, Mészáros László, újabb leleteket adott át, melyek a temető területéröl származnak. ${ }^{15}$ A leletek egy része sírból származhatott. 2005-ben, a lelőhelyen végzett feltárás során, újabb sír nem került elő. ${ }^{16} \mathrm{Az}$ egykori agyagbányától délre, 3 . századi temető került elő. ${ }^{17}$

\section{A sirlelet:}

1. Bronzfibula

Hagymafejes fibula, a középső gomb hiányzik. A két megmaradt szélső gomb közötti rész bordázott, a kengyel rovátkolt. A vastü töredéke belekorrodálódott a bordákkal és koncentrikus körökkel díszített tütartóba. Tör. H: $8,3 \mathrm{~cm}$. Sz: 4,9 cm. M: 2,7 cm. Ltsz: R.94.99.1. (l. t. 5.).

8 Kuzsinszky 1920, 34

9 Sági 1973. KÖH 19808. lelöhely.

10 Sági 1973, 289

11 Eöry 1999, 34.

12 Eöry Béla helytörténész (Balatonberény) tájékoztatását ezúton is köszönöm.

13 Magyar Kálmán leletmentése, 1973. november 3. RRM A. 400.

14 M. Hrotkó Zsuzsa-Kling József leletmentése 1974. március 13. RRM.A. 897. A publikációban használt rövidítések: H: hosszúság, Sz: szélesség, Szá: szájátmérő, Fá: fenékátmérő, Á: átmérő, $M$ : magasság, V: vastagság, Fv. : falvastagság, Tör.: töredék, Ltsz leltári szám.

15 M. Hrotkó Zsuzsa- Kling József helyszínelése 1974. március 20. RRM.A. 898. Régészeti Füzetek I. 28. (1975) 35.

16 Honti et al. 2007, 49

17 Honti et al. 2007, 51. és 56. A feldolgozást Hajdú Ádám végzi. 


\section{Bronz övcsat}

A téglalap alakú csattesten nyíl alakú bevésett díszítés látható. Végződése és a pecek bordákkal tagolt. A csattesten a felerősítő bronzszegecs megmaradt. $\mathrm{H}: 4,1 \mathrm{~cm}$. Sz: 3,4 cm. V: 0,4 cm. Ltsz: R.94.99.2. (I. t. 6.).

3. Vaskés

Ívelt hátú vaskés, töredékes markolattüskével. Hegye hiányzik, a penge széle töredezett. Tör. H: 15,7 $\mathrm{cm}$. Sz: $3,2 \mathrm{~cm}$. A markolattüske $\mathrm{H}: 3,9 \mathrm{~cm}$. Ltsz: R.94.99.10. (I. t. 3.).

4. Vastárgy töredéke

Négyzet keresztmetszetű vastárgy kisebb, erősen korrodálódott töredéke, esetleg cece (radius) darabja. Tör. H: 6,8 cm. Sz: 0,5 cm. Ltsz: R.94.99.11.

5. Érmék

Ltsz: R. 94.99.3-9.

3. századi dénár vagy antoninianus

I. Valentinianus

AE3 Siscia 367-375 RIC 14a/17

H.: GLORIA ROMANORVM - császár áll labarumot tartva és lenyom egy ellenséget típus, // BSISC M / $P$ felette csillag

Valens

AE3 Siscia 367-375 RIC 14b/10

H.: GLORIA ROMANORVM - császár áll labarumot tartva és lenyom egy ellenséget típus, // ]SISC / R

I. Valentinianus

AE3 Siscia 367-375 RIC 15a/10

H.: SECVRITAS REI PVBLICAE - Victoria megy balra, kinyújtott kezében koszorút, vállán pálmaágat tart típus, // (SISC) R /

Valentinianus dinasztia

AE3 364-378

H.: SECVRITAS REI PVBLICAE - Victoria megy balra, kinyújtott kezében koszorút, vállán pálmaágat tart típus

II. Constantius

AE3 351-358

H.: FEL TEMP REPARATIO - császár ledöfi az ellenséges lovast típus

Valentinianus dinasztia

AE3 364-378

H.: SECVRITAS REI PVBLICAE - Victoria megy balra, kinyújtott kezében koszorút, vállán pálmaágat tart típus

\section{Szórványleletek a temető területéről:}

1. Bronzfibula

Hagymafejes fibula, a tüje hiányzik. A két szélső gomb közötti rész bordázott, a kengyel rovátkolt és rovátkolt bordával díszített. A tűtartó rovátkolásokkal és koncentrikus körökkel díszített $\mathrm{H}: 8,2 \mathrm{~cm}$. Sz: 4,8 cm. M: 2,7 cm. Ltsz: R.94.102.1. (I. t. 1.).

2. Vasnyílhegy

Töredékes nyílhegy. Hosszúköpüs, a penge rombusz, a köpủ négyzet keresztmetszetü. $\mathrm{H}: 7,2 \mathrm{~cm}$. A köpü H: 3,1 cm. Sz: 0,8 cm. Ltsz: R.94.102.2. (I. t. 4.).

\section{Vaskarika}

Töredékes vaskarika, belsejéhez famaradvány oxidálódott. Á: $3,4 \mathrm{~cm}$. Sz: $1,7 \mathrm{~cm}$. V: $0,2 \mathrm{~cm}$. Ltsz: R.94.102.3. (I. t. 2.).

4. Vaskarika töredékei

Vaskarika 2 töredéke, belsejéhez famaradvány oxidálódott. $\mathrm{cm}$. Sz: $1,5 \mathrm{~cm}$. V: $0,2 \mathrm{~cm}$. Ltsz: R.94.102.4.

5. Vaskés töredékei

Vaskés erősen korrodálódott töredéke ( $3 \mathrm{db}) \mathrm{Sz}: 2$ cm. Ltsz: R.94.102.5.

6. Vastárgy töredékei

Négyzet keresztmetszetü vastárgyak erősen korrodálódott töredékei (4 db). Esetleg cece (radius) darabjai. Sz: 0,8 cm. Ltsz: R.94.102.6.

A vaskés római kori temetőben gyakori melléklet, a rádpusztaihoz hasonló tárgy a somogyszili temető 29. sírjából került elő. ${ }^{18}$ A vaskarika, melynek belsejéhez famaradvány oxidálódott, faeszköz vasalása lehetett. A töredékes vasnyílhegyhez hasonló tárgy az intercisai temető 1129. sírjából került elő. ${ }^{19}$

A rádpusztai fibulák a Keller-Pröttner 3-4. típus $B$ változatához tartoznak és 330-400 közé keltezhetők. ${ }^{20}$ A bronzcsat párhuzama a mözsi temető 6 . sírjából ismert és a 360-as évekre keltezhető. ${ }^{21}$ A temetkezésre a 4. század végén kerülhetett sor, melyet a sírból származó érmék is megerősítenek.

\section{Balatonszabadi - Siómaros}

A temetőben lévő Sashalom vagy más néven Basahalom, nagyobb domb, kétséges, hogy halmos temetkezést rejtene..$^{22} \mathrm{~A}$ Sashalomtól északkeletre, Laczkó Dezső szerint, „kifosztott” római temető található. ${ }^{23}$ 1964-ben, a temetődomb nyugati részén, 3 kisbronz, 1 nagybronz és 2 terra sigillata utánzat került elő. ${ }^{24}$ 1977-ben, a Sashalom környékén, római kori hamvasztásos temetőből származó lelet került elő. ${ }^{25}$

\section{Fazék töredékei}

Kihajló, ferdén levágott peremű fazék töredékei, a vállon árkolások futnak körbe. Kaviccsal soványított, egyenetlenül kiégetett, barna-fekete. Fá: $9 \mathrm{~cm}$. Fv.: 0,8 cm. Ltsz: R.94.10.1. (I. t. 7.).

A fazéktípus az 1. é 2. század fordulójára keltezett temetőkben fordul elő, Somogy megyéből, a somogyaszalói 1. halomban kerültek elő hasonló darabok. ${ }^{26}$

\footnotetext{
18 Sz. Burger 1979, 27. Taf. 5. és Taf. 39.7

19 B. Vágó-Bóna 1976, 83. Taf. 19.

20 Pröttel 1988, 359. és 362

21 Gaál 1979. 29. és 58. 16. kép 1. és 31. kép.

22 Csizmadia-Németh 2016, 119

23 Laczkó 1912, 15

24 Magyar Kálmán feljegyzése. RRM A. 827. A leletek magántulajdonban maradtak.

25 Wollák Katalin leletmentése. RRM A. 833. KÖH 19395. lelöhely A közlés jogának átengedését Wollák Katalinnak ezúton is köszönöm.

26 Csizmadia-Németh 2016, 128-9. VI. t. 1. és 9
} 
Az 1994-ben végzett terepbejárás során leleteket nem lehetett gyűjteni, de feltételezhető, hogy kora római, hamvasztásos temető további sírjainak előkerülésével még számolni lehet. ${ }^{27}$ 2009-ben, a lelőhelytől északkeletre, római telepnyomok kerültek elő. ${ }^{28}$

\section{Balatonszabadi - Homokbánya}

Az előző lelőhely közelében lévő homokbányából, Székely György (Balatonszabadi, Kossuth u. 40.) leleteket gyűjtött össze, melyek, elmondása szerint, csontvázas sírok mellékletei voltak. ${ }^{29} \mathrm{Az}$ ékszerekkel együtt bekerült tál, kerámiatöredékek és embercsontok ma már nem azonosíthatóak.

\section{Bronzkarperec}

Nyitott bronzkarperec, végei rovátkolással kiemelt, kettős koncentrikus körrel díszítettek, majd két, V-alakú rovátkolás látható, melyeket háromszoros, meröleges sor tagol. A díszítést koncentrikus körök zárják le. Á: $5,9 \mathrm{~cm}$. Sz: 0,5 cm. V: 0,1 cm. Ltsz: R.94.9.2. (II. t. 7.).

2. Bronzkarperec

Nyitott bronzkarperec, vége $\mathrm{V}$-alakú rovátkolással díszített. Á: $6,3 \mathrm{~cm}$. Sz: 0,4 cm. V: $0,1 \mathrm{~cm}$. Ltsz: R.94.9.1. (II. t. 4.).

3. Bronzgyürü.

Két darabra tört, díszítetlen bronzgyürü. Á: $2 \mathrm{~cm}$. Sz: 0,5 cm. V: 0,1 cm. Ltsz: R.94.9.3. (II. t. 5-6.).

A bronzkarperecek stilizált kígyófejben végződnek, és a 4. század 2. felére, végére keltezhetőek. ${ }^{30} A 4$. századra keltezhető a díszítetlen bronzgyűrü. ${ }^{31}$

\section{Balatonszemes - Árnyas fasor 1. \\ Római sírkő, Pilisvörösvárról került Balatonsze- mesre. ${ }^{32}$}

\section{Balatonszentgyörgy - Battyánpuszta}

A 2. világháború idején római sír került elő, aranymelléklettel. A sír, melynek lelete nem maradt meg, Battyánpusztától északra, ahol az országút metszi a halastavak lefolyását, került elő. ${ }^{33}$

27 Németh Péter Gergely terepbejárása. RRM A. 609

28 Honti Szilvia-Molnár István-Németh Péter Gergely terepbejárása. RRM A. 3446.

29 Wollák Katalin útijelentése, 1977. RRM A. 833. és 834. A közlés jogának átengedését Wollák Katalinnak ezúton is köszönöm. KÖH 19398. lelöhely.

30 V. Péterfi, 1993, 86

31 V. Péterfi, 1993, 87.

32 Sági-Cséby 1990, 70-72. KÖH 19790. lelöhely. A továbbiakban, a sírkőtöredékeket nem említem, mert a lelöhely nagyon sok esetben bizonytalan és a legtöbb esetben, csak másodlagosan elökerült sírkőröl beszélhetünk. A Somogy megyei sírkövekhez I. Fehér- Kovács 2017

33 Keszthelyi Balatoni Múzeum Adattára (a továbbiakban: KBM A.) 61.96.4. és RRM A. 5475. KÖH 19745. lelöhely. Futó István vörsi lakos szerint, a sír a vörsi határban került elö. Tájékoztatását ezúton is köszönöm.

\section{Balatonszentgyörgy - Battyánpuszta-Vörsi út}

1959-ben, a 15. számú ház elött, útépítés során, urnasír, 1960-ban néhány hamvasztásos sír került elő. ${ }^{34}$

\section{Balatonszentgyörgy}

1968-ban, vízelvezető csatorna ásásakor előkerült kora római telep és késő római temető leletmentését végezte el Sági Károly. ${ }^{35} \mathrm{~A}$ temetőhöz 8 csontvázas sír tartozott.

\section{Balatonszentgyörgy - Kastély-dülő 1. lelőhely}

A Kastély-dűlőn magányos római kori sír került elö, leletek nem kerültek be a kaposvári múzeumba. A 2006. évi terepbejárás során, kis területen kerültek elő római kori téglák. ${ }^{36}$

\section{Balatonszentgyörgy - Battyáni disznólegelő}

Késő római sírok kerültek elő a telepen belül. ${ }^{37}$

\section{Balatonújlak - Felső-dűlő}

A község déli végénél, az út nyugati oldalán, téglasír került elö, teteje terazzoszerü, melléklet nélküli csontvázzal. ${ }^{38} \mathrm{~A}$ temető helyének pontos lokalizálása bizonytalan, közelében villa található, a bejárás során itt 4. századi érme került elő. ${ }^{39}$

\section{Barcs - Háromfai országút}

1929-ben, „dongaboltozatos” sír került elő. A csontvázas sírban fegyvereket és eszközöket találtak. Nem dönthető el, hogy a római korba tartozott-e, leletek nem kerültek be a kaposvári múzeumba. ${ }^{40}$

\section{Bonnya}

1934-ben, téglasírból származó leletek kerültek be a kaposvári múzeumba. A sírban tál, bronzkarkötők, vastárgyak (köztük vaskés), üveggyöngyök és $14 \mathrm{db}$ érme volt. $A$ vaskés és az érmék nem kerültek be a múzeumba. ${ }^{41}$ Kocztur Éva két sírról tesz említést, de az adattár alapján csak ez az egy téglasír került elő. ${ }^{42}$

\section{Edény}

Behajló peremü, talpgyürüs edény, három, tagolt füllel. Árkolásokkal és rádli sorokkal díszített. Porózus, világosbarna, zöld mázzal. Kiegészített. Szá: 19 cm. Tá: 7,1 cm. M: 11,7 cm. Ltsz: 8942. (II. t. 1 . és 1. ábra.).

34 KBM A. 61.96.1. és 4. és RRM A. 5477. Kocztur 1964, 21. KÖH 19739. lelöhely.

35 Régészeti Füzetek I/22 (1969), 5. A leletek a Keszthelyi Múzeumba kerültek. Ltsz.: KBM. 69.171.1.-69.208.1.

36 Honti Szilvia és Németh Péter Gergely terepbejárása. RRM A. 3498. KÖH 54715. lelöhely. A sírra Eöry Béla helytörténész (Balatonberény) hívta fel a figyelmünket, tájékoztatását ezúton is köszönöm.

37 A sírleletek a telepfeldolgozással együtt kerülnek később közlésre. KÖH 19737. lelöhely.

38 Kuzsinszky 1920, 33. KÖH 19729. lelöhely.

39 Honti Szilvia és Németh Péter Gergely terepbejárása. RRM A 859.

40 RRM A. 8088. KÖH 19603. lelöhely.

41 RRM A. 918. Kocztur 1964, 27. KÖH 19651. lelőhely.

42 2015-ben, régészeti megfigyelés során, nem került elő régészet lelet és a római temető lokalizációja sem volt lehetséges. RRM A. 7308 


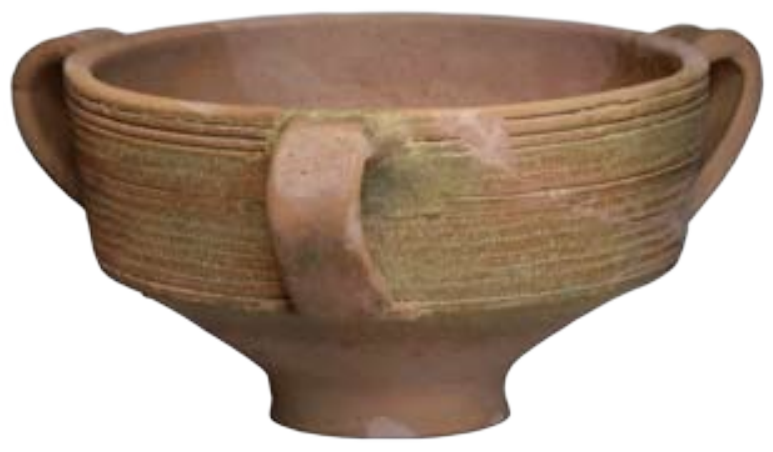

1. ábra. A bonnyai mázas edény

\section{Bronz karperecpár}

Kör keresztmetszetű, egymásra hajló végű bronzkarperecek, rovátkolással kiemelt, koncentrikus körökkel díszítettek. Á: $5,3 \mathrm{~cm}$. V: $0,1 \mathrm{~cm}$. Ltsz: 8944-5. (II. t. 2-3.).

3. Vas cece (radius)

Kör keresztmetszetü, elkeskenyedő végü, töredékes. Tör. H: 25,6 cm. V: 1,1 cm. Ltsz: 8943. (II. t. 8.).

4. Gyöngyök

$4 \mathrm{db}$ üveggyöngy. Elvesztek. A kék színű gyöngyök közül kettő lencse alakú, a másik kettő, eltérő nagyságú, hasáb alakú volt, a kisebbik rombusz alakú díszítéssel.

5. Sírtéglák

2 db sírtégla. Elvesztek. Vörösessárga színűek, magasságuk $48 \mathrm{~cm}$, szélességük $32,5 \mathrm{~cm}$, vastagságuk $6 \mathrm{~cm} .^{43}$

A sír háromfülü, mázas edényéhez hasonló, de kisebb méretű darabok, több római temetőben is előkerültek, és a 4 . század közepe után készültek. ${ }^{44}$ A bronzkarperecek stilizált kígyófejben végződnek és a 4. század 2. felére, végére keltezhetők. ${ }^{45}$ A cece (radius) korábban nyársként, majd kézi guzsalyként szerepelt a szakirodalomban. Pásztókai-Szeőke Judit határozta meg a kétgerendás szövőszéken, a függőleges fonatok kiemeléséhez szükséges eszközként. ${ }^{46} A$ tárgytípus leggyakrabban, 4. századi, női sírokból származik. ${ }^{47}$ A telepeken elökerült leleteket is figyelembe véve, a tárgytípus leggyakrabban a Balaton környékén, és a tótól délre került elö. ${ }^{48}$

\section{Bonnya - Belterület, Kisiskola}

1959-ben, Bunyevácz J. és Szvetics M. szérüjén, silógödör ásásakor, csontvázas sírok kerültek elö, melyekben csontfésü, gyürü, gyöngy volt. A leletanyag nem került be a múzeumba. A leírás alapján a teme-

\footnotetext{
43 A gyöngyök és a sírtéglák leírása a korabeli tárgykarton alapján készült.

44 Nádorfi 1992, 5. Katalog 247

45 V. Péterfi, 1993, 86.

46 Pásztókai-Szeőke 2012

47 Rupnik 2014, 131

48 Rupnik 2014, 132-133. és 84. ábra.
}

tő római vagy népvándorlás kori lehetett. A környéken többször került elő sír. ${ }^{49}$

\section{Bőszénfa}

A szentegyedi baromfarmról, római temető említése szerepel az adattárban. A lelőhely valójában Szentlászlóhoz (Baranya megye) tartozik, további adat nem ismert, leletek nem kerültek be a kaposvári múzeumba. ${ }^{50}$

\section{Buzsák - Táska u. 415.}

Lukács Sándor 1939-ben, verem ásásakor, két, téglából épített sírkamrát talált, melyben három csontváz volt. A tárgyak a sírleletek szétválasztása nélkül kerültek be a kaposvári múzeumba. Jelenleg két üvegedény és egy vastárgy van meg. ${ }^{51}$ A két üvegedény közül az egyikben érmék voltak, a tálban állatcsontok. Felszíni leletek alapján (tégla- és edénytöredékek), temető az utca másik oldalán, ha keskeny sávban, is folytatódott. ${ }^{52} \mathrm{~A}$ falu területén feliratos kőemlékek kerültek elő, amelyek esetleg máshonnan származnak, talán a közeli Csisztapusztáról. ${ }^{53}$

\section{1. Üvegkorsó}

Kihajló peremü, kockatestű edény, szükülő nyakkal és bordázott szalagfüllel. Oldalai benyomottak, világoszöld színü. Szá: $6,7 \mathrm{~cm}$. M: $17 \mathrm{~cm}$. Fá: $11 \mathrm{~cm}$. Ltsz: 11151. (I. t. 9.).

2. Üvegtál

Behajló peremü tál. Vágott peremü, oldalán bordázott, zöldesfehér színü. Szá: $13 \mathrm{~cm}$. M: $4,5 \mathrm{~cm}$. Ltsz: 11151. (I. t. 8.).

3. Vasgyürü

Durva kidolgozású, vastag vasgyürü. Formája és mérete alapján inkább újkori, a római sírokhoz való tartozása erősen kérdéses. Á: $6,8 \mathrm{~cm}$. V: $0,8 \mathrm{~cm}$. Ltsz: 11153.

\section{A hiányzó tárgyak: ${ }^{54}$}

4. Tál Kihajló peremű, alacsony tál. Á: 17,5cm.

5. Aranygyürü Zöldkő betétes aranygyűrü. Á: 1,8-1,9 cm.

6. Fülbevaló Enyhén deformálódott, a függőrészen kőbetétnek nem látszik nyoma. Á: $1,5-1,6 \mathrm{~cm}$.

7. Aranycsüngő Mindkét végén kapcsoló karikával, közte kékszínü gyönggyel. $\mathrm{H}: 2 \mathrm{~cm}$.

8. Bronzfibula Ép hagymafejes bronzfibula, „finom kidolgozásban, szép bevágásos díszítésekkel”. $\mathrm{H}: 7,5 \mathrm{~cm}$.

49 Kocztur Éva terepbejárása 1961-ben. Kocztur 1964, 27. KÖH 47211. lelöhely.

50 Draveczky - Sági - Takáts 1964,17.

51 RRM A. II/9/5. KÖH 19659. lelöhely, Olajfúró-torony elnevezéssel.

52 Radnóti Aladár helyszínelése 1939-ben. Magyar Nemzeti Múzeum Adattára (a továbbiakban MNM A.) 62.B.I. és RRM A. II/9/12.

53 RRM A. II/9/10. és MNM A. 99.B.II. KÖH 19666. lelöhely.

54 A hiányzó tárgyak leírása a leltárkönyv és a korabeli tárgykarton alapján készült. 
9. Vastárgy töredékei

Valószínủleg cece (radius) lehetett.

10. Érmék

26 vagy $33 \mathrm{db}$ érme, nem azonosíthatók, kérdéses, hogy bekerültek-e a múzeumba.

12. „Bronzfoglalat”

Nem azonosítható tárgy, kérdéses, hogy bekerült-e a kaposvári múzeumba.

Az üvegkorsó készítési ideje az 1-2. század,,55 ugyanakkor az üvegtál, ${ }^{56}$ és a hiányzó tárgyakról fennmaradt, egyszerű rajzok alapján, a temető leleteinek többsége inkább a 4. századra keltezhető.

\section{Büssü - Halastói agyagbánya}

1950-ben sír került elő, a leletek Fellegi Bálint és Nagy Mózes Lajos ajándékaként kerültek be a kaposvári múzeumba. ${ }^{57} \mathrm{~A}$ vállnál bronzfibula került elö, a medencénél sárgás üvegedény szilánkjai voltak, ezek már nem azonosíthatóak a múzeumban. A bokák között bronzcsat- és szíjbújtató, valamint egy érem volt, a jobb térdnél egy másik érme, a többi érme előkerülési helyét nem ismerjük. A bal bokánál bronzgomb volt. A bronz és - ezüstgyürü elhelyezkedése bizonytalan. A jobb lábszárcsontnál voltak a vaseszközök és a kovadarabok.

1. Bronzfibula

Hagymafejes fibula, a tüje hiányzik. A kengyel ferde rovátkolással, a láb hasonló díszítéssel és koncentrikus körökkel díszített. H: $8 \mathrm{~cm}$. Sz: $5,1 \mathrm{~cm}$. M: $3 \mathrm{~cm}$. Ltsz: 50.10 .1 . (III. t. 1.).

2. Bronzcsat

Csuklós szerkezetű, propellerveretes, bordázott díszítésű bronzcsat, kettős csattüskével. A csattüske kisebb sérülésétől eltekintve ép. H: $5 \mathrm{~cm}$. Sz: 5,2 cm. Ltsz: 50.10.2. (III. t. 2.).

3. Ezüstgyürü

Sokszögletü, ép ezüstgyürü, függöleges pontsorokkal díszítetett. A díszítés egyenetlen és a gyürü forrasztása nem eldolgozott Á: $2,2 \mathrm{~cm}, S z: 0,4 \mathrm{~cm}$. Ltsz: 50.10.6. (III. t. 3.).

4. Bronz pecsétgyürü

Kör alakú, vésett díszítéssel. A fej két oldalán granulációt utánzó kiemelkedéssel. Á: $1,8 \mathrm{~cm}$. A fej Á: $112 \mathrm{~cm}, \mathrm{~V}: 0,2 \mathrm{~cm}$. Ltsz: 50.10 .3 . (III. t. 5.).

5. Bronzgomb Töredékes bronzgomb, a belső szára hiányos. Á: 2 cm. M: 0,7 cm. Ltsz: 50.10.4. (III. t. 4.).

6. Bronzlemez Meghajlított, ép bronzlemez. H: 0,9 cm. Sz: 0,6 cm. Ltsz: 50.10.5. (III. t. 6.).

7. Kovadarabok Barna $(2 \mathrm{db})$ és zöld színü (1 db) kovadarabok. Átlagos H: 2,8 cm. Sz: 2 cm. Ltsz: 50.10.27-29.

55 Csizmadia 1998, 97.

56 Csizmadia 1998, 91

57 Takáts Gyula kiszállása. RRM A. 7329. és Kocztur 1964, 32-33. KÖH 19701. lelöhely.
8. Vasár

Négyzet keresztmetszetü, a nyéltüskéje elkeskenyedő. H: 8,9 cm. Sz: 1,3 cm. Ltsz: 50.10.30. (III. t. 7.).

9. Vaskés töredékei

Enyhén ívelt hátú vaskés 3 töredéke. A markolattüske hiányos. A legnagyobb töredék $\mathrm{H}: 6,9 \mathrm{~cm}$. Sz: 2,5 cm. Ltsz: 50.10.30. (III. t. 8-9.).

10. Vastárgy töredékei

Kör keresztmetszetü vastárgy, esetleg cece (radius) két töredéke. $\mathrm{H}: 3,5$ és $2,6 \mathrm{~cm}$. Á: $0,5 \mathrm{~cm}$. Ltsz: 50.10 .30 .

11. Vastárgy töredéke

Négyzet keresztmetszetü, elkeskenyedő végű vastárgy (esetleg késnyél) töredéke. $\mathrm{H}: 5,3 \mathrm{~cm}$. Sz: 0,4 cm. Ltsz: 50.10.30.

12. Érmék

A bokák között egy érme volt, a jobb térdnél egy másik, a többi érme előkerülési helyét nem ismerjük. Két érme nem került be a múzemba. Ltsz: 50.10.7-26.

Constans

AE3 Siscia 348-350 RIC 241-242

H.: FEL TEMP REPARATIO - phőnix máglyán típus, // ASISh

II. Constantius

AE2 Cyzicus 351-354 RIC 92

H.: FEL TEMP REPARATIO - császár ledöfi az ellenséges lovast típus, // SMK $\triangle$ Г/

II. Constantius

AE3 Thessalonica 348-350 RIC 119

H.: FEL TEMP REPARATIO - császár áll labarummal hajón, mögötte Victoria kuporog típus, // TES $\triangle$

Constans

AE3 Siscia 348-350 RIC 241

H.: FEL TEMP REPARATIO - phőnix máglyán típus, // ASISh

Constans

AE3 Siscia 348-350 RIC 241

H.: FEL TEMP REPARATIO - phőnix máglyán típus, // ASISh

Constans

AE3 Siscia 348-350 RIC 244

H.: FEL TEMP REPARATIO - császár áll labarummal hajón, mögötte Victoria kuporog típus, // ASISh

Constans

AE3 Siscia 348-350 RIC 236

H.: FEL TEMP REPARATIO - phőnix máglyán típus, // BSIS kampó

Constans

AE3 Siscia 348-350 RIC 236, 241

H.: FEL TEMP REPARATIO phőnix máglyán típus, // ASIS?

Constans

AE3 Siscia vagy Sirmium 348-350

H.: FEL TEMP REPARATIO - császár áll labarummal hajón, mögötte Victoria kuporog típus, // ]SI[

II. Constantius

AE3 Siscia 348-350 RIC 243 
H.: FEL TEMP REPARATIO - császár áll labarummal hajón, mögötte Victoria kuporog típus, // ESISh Constans

AE3 Siscia 348-350

H.: FEL TEMP REPARATIO - császár áll labarummal hajón, mögötte Victoria kuporog típus, // ]SIS[ Constans

AE3 348-350

H.: FEL TEMP REPARATIO - császár áll labarummal hajón, mögötte Victoria kuporog típus

Constans

AE3 Siscia 348-350 RIC 244

H.: FEL TEMP REPARATIO - császár áll labarummal hajón, mögötte Victoria kuporog típus, // ASISh

Constans

AE3 Siscia 348-350

H.: FEL TEMP REPARATIO - császár áll labarummal hajón, mögötte Victoria kuporog típus, // ]SIS[ Constantius Gallus

AE2 Sirmium 351-354 RIC 29

E.:A /

H.: CONCORDIA MILITVM - katona két labarummal áll szemben típus, // SIRM III

II. Constantius

AE4 Siscia 337-340 RIC 85

H.: GLORIA EXERCITVS - két katona között egy katonai jelvény típus, // ESIS

Constans

AE4 Siscia 347-348 RIC 189

H.: VICTORIAE DD AVGG Q NN - két Victoria

szemben állva koszorúkat nyújtanak egymásnak típus, 'ASIS. mezőben középen $\mathrm{N}$

II. Constantius

AE3 Siscia 348-350 RIC 243

H.: FEL TEMP REPARATIO - császár áll labarummal hajón, mögötte Victoria kuporog típus, // BSISh

II. Constantinus

AE4 Cyzicus 330, 334 RIC 67

H.: GLORIA EXERCITVS - két katona között két katonai jelvény típus, // SMK $\Delta$. Constans

AE3 Siscia 348-350 RIC 234

H.: FEL TEMP REPARATIO - császár áll labarummal hajón, mögötte Victoria kuporog típus, // BSIS.

A bronzfibula (III. t. 1.) a Keller-Pröttner 3-4. típus B változatához tartozik és 330-400 közé keltezhető. ${ }^{58}$ A 4. században készült az ezüstgyürü (III. t. 3.). ${ }^{59}$ A 4. század első felére keltezhető a bronz pecsétgyürü (III. t. 5.). ${ }^{60}$ A bronzcsat a Gala típusú övekhez tartozik, készítési ideje a 4. századra tehető, de használata az 5. század első felére is áthúzódhat. ${ }^{61} A$ vasár, római telepleletek mellett, temetkezésekben is előfordul. ${ }^{62}$

58 Pröttel 1988, 359. és 362.

59 V. Péterfi, 1993, 87.

60 R. Facsády 2009, 95. Tárgykatalógus 30

61 Nagy 2004, 243-4.

62 Rupnik 2014, 153-4
A hajlított bronzlemez (III. t. 6.) talán szíjbujtatóként szolgált. A bronzgomb (III. t. 4.) és a kovadarabok pontos keltezésre nem alkalmasak. Az egyéb mellékleteket az érmekkel összevetve, a temetkezésre a 4 . század 2. felében kerülhetett sor.

Büssü területéröl több római kori temetőről is van adatunk, de ezek, részben egy temetőtőre vonatkozhatnak. A Halastói agyagbányai és a Dohányos-dűlői lelöhely minden bizonnyal azonos. ${ }^{63}$

\section{Büssü - Dohányos-dülő}

Temető, leletek nem kerültek be a kaposvári múzeumba. ${ }^{64}$

\section{Büssü - Páfrányosi-mező}

Temető, leletek nem kerültek be a kaposvári múzeumba. ${ }^{65}$

\section{Büssü - Pap-erdő}

1880-ban sír került elő, leletek nem kerültek be a kaposvári múzeumba. ${ }^{66}$

\section{Büssü - Gór-domb}

Temető, leletek nem kerültek be a kaposvári múzeumba. ${ }^{67}$

\section{Csoma - Nyúlházi-dűlő \\ Késő római téglasír. ${ }^{68}$}

\section{Ecseny - Öreghegy}

Mintegy 10 sír került elő, a leletek nem kerültek be a múzeumba. A sírokban ékszerek és érmék, a halottak feje mellett egy-egy kődarab volt. ${ }^{69}$ Pusztai Dezső helyszínelése alapján nagyon valószínü, hogy ezek a sírok nem a római kori, hanem a középkori temetőhöz tartoztak. ${ }^{70}$

\section{Fonó}

Az 1950-es évek végén a község határában több téglasírt találtak, leletek nem kerültek be a múzeumba. Nem eldönthető, hogy a sírok milyen korba tartoztak. ${ }^{71}$

\section{Fonyód - Sándor u. 26.}

A római villa környékén melléklet nélküli, csontvázas sírok kerültek elő, Magyar Kálmán ezeket feltételesen a római korba sorolta. ${ }^{72}$ Újabb tanulmánya alapján azonban, a középkori temetöhöz tartozhattak. ${ }^{73}$

63 RRM A. 2212.

64 Berta Gyula elmondása szerint 3 csontvázas sír került elö, éremmelléklettel. Németh Péter Gergely terepbejárása, 2012. RRM A. 3133. Berta Gyula tájékoztatását ezúton is köszönöm. KÖH 61138. lelöhely.

65 RRM A. 7329. Kocztur 1964, 33. KÖH 19703. lelöhely.

66 RRM A. 7329.Kocztur 1964, 33. KÖH 19704. lelöhely.

67 Kocztur 1964, 33. KÖH 19702. lelöhely.

68 Németh 1996. KÖH 19464. lelöhely.

69 RRM A. 7354-5. KÖH 20532. lelöhely.

70 RRM A. 7358

71 Kocztur 1964, 39

72 Magyar 1985, 34

73 Magyar 2016 


\section{Gölle - Labdarúgópálya}

A község nyugati végénél, Galambos Sándor földjén, téglasír került elö. A csontváz lábánál agyagedény volt, benne ezüstérmék. A feltételesen 4 . századi leletek elkallódtak. ${ }^{74}$

\section{Gyékényes - Kavicsbánya}

1890 óta leletek kerültek elő a bányából, melyek egy része temetöhöz tartozhatott. ${ }^{75}$ 1943-ban újabb leletek és csontvázak kerültek elő. ${ }^{76}$

\section{Gyékényes - Közúti kavicsbánya}

1980-ban, melléklet nélküli, csontvázas téglasír került elö. ${ }^{77}$

\section{Gyugy - Homokbánya}

A templom és a cigánytelep közötti homokbányában, 5-7 téglasír került elö, melléklet nem volt. Müller Róbert szerint, a téglák mérete alapján, a sírok római koriak lehetettek. ${ }^{78}$

\section{Igal - Homokbánya}

1960 őszén, a homokbányában, csontvázas sírlelet került elö. Jobb karja mellett vas lándzsahegy, lábánál üvegtál, üvegkorsó és agyagtál volt. A csontvázon „szétszórva” $18 \mathrm{db}$, 4. századi érme. A kaposvári múzeumba az agyagtál és a két üvegedény került be. ${ }^{79}$ A homokbányából több ízben kerültek elő sírok $.^{80} 2015-$ ben, Berta Gyula, egykori igali lakos, megmutatta azt a Gábor utcai területet, ahol a sír elökerült. Berta Gyula elmondása szerint, az egykori temetőt keletről határoló magas partfalban települési objektumok is voltak, egy félbevágott, nagyon mély objektumra (véleménye szerint kútra) emlékezett, melyböl nagyon sok római kori kerámiatöredék került elö. ${ }^{81}$

1. Töredékes üvegkorsó

Behajló peremü üvegkancsó trapéz alakú füllel, alacsony talpgyürüs. A száján üvegszál, mely a

74 Pusztai Rezső leletmentése 1957-ben. RRM A. 7413. KÖH 20583. lelöhely. Kocztur Éva említ még Gölléből előkerült téglasírt, mely a vásártértöl nyugatra került elő, lehet, hogy a Labdarúgópályán előkerült sírra vonatkozik. Kocztur 1964, 53. Ugyancsak Ő említ egy további sírt is, melyet 1953-ban találtak a Felsőhetény és Nak közötti erdöben, így feltehetően már Tolna megye területére esik. A valószínűleg késő római kori sír melléklete korsó, vaslándzsa és több érem volt. Kocztur 1964, 52.

75 Fröhlich Róbert leletmentése. Archaeológiai Értesítő 1891, 226. KÖH 26631. lelöhely

76 RRM A. 7889. Nem dönthető el, hogy melyik tárgy tartozott temetkezéshez.

77 A leletmentést a kaposvári múzeum egykori munkatársa, Merész Emese és testvére, Merész István végezte el, akinek a tájékoztatást ezúton is köszönöm. Németh Péter Gergely helyszínelése 1988-ban. RRM A. 109. A kiválogatott sírtéglák a barcsi múzeumba kerültek. KÖH 26626. lelöhely

78 Müller Róbert terepbejárása, 1965. RRM A. 5770. KÖH 20351. lelöhely

79 Csik Ernő leletmentése. A leltárkönyv bejegyzése szerint övveretek és ládikaveretek is előkerültek, de a kaposvári múzeumba már nem jutottak el. Nem eldönthető, hogy ebben, esetleg egy másik sírban voltak a már eltünt tárgyak. RRM A. IV/23/8. KÖH 25579. lelöhely

80 Frech Miklós helyszínelése 1961-ben. Archaeológiai Értesítő 1961. 288 és Régészeti Füzetek Ser. I. No. 14. 33.

81 Berta Gyula tájékoztatását ezúton is köszönöm. nyakra is ráhúzódik, kékeszöld. Szá: $6,4 \mathrm{~cm}$. Tá: 5,1 cm. Ltsz: 61.287.1. (III. t. 10., 13-14.).

\section{2. Üvegtál}

Behajló peremü tál, kannelurával díszített, fehér színü. A perem kisebb sérülésététől eltekintve ép. Szá: 12,7 cm. M: 3,4 cm. Ltsz: 61.288.1. (III. t. 12.).

3. Tál

Behúzott peremű alacsony tál, az edénytesten jól látható korongolás nyomokkal. Pereme sérült, az alján lévő bekarcolás is sérülésnyom. Kopott, szürke-sötétszürke. Szá: 14,3 cm. Fá: 9,2 cm. M: 4,6 cm. Ltsz: 61.288.1. (III. t. 11.).

Az üvegtál a 4. században készült. ${ }^{82} A$ töredékes üvegkorsó szintén a 4. századra keltezhető. ${ }^{83} A z$ agyagtál keltezése megegyezik az üvegedényekkel. ${ }^{84}$

\section{Igal - Csuhusi-dűlő}

A település délkeleti részén, a Rozbeli-vízfolyástól nyugatra, Berta Gyula tájékoztatása szerint, itt korábban két téglasírt szántottak szét, melléklet nem volt. ${ }^{85}$ A 2008. évi terepbejárás során, a lelőhelyen, középkori érme és vastárgyak mellett, néhány jellegtelen római kori kerámiatöredékeket találtunk. ${ }^{86}$

\section{Kapoly - Kapolypusztai elágazás}

A szántódi úttól keletre, a Kapoly-Tab úttól északra, kb. 40 sír pusztult el. Az egyik, nagy, négyszögletes téglákkal körülvett, észak-déli tájolású, csontvázas sírban, a mellrészen fibula, a lábnál „tőrkés” és kis füles korsó volt. A csontváz mellett szarvasagancs és díszes üveggyöngyök is voltak. ${ }^{87} \mathrm{~A}$ múzeumba, a sírból, a fibula került be, valamint üvegedény töredéke, amely szintén sírlelethez tartozhatott.

\section{Bronzfibula}

Hagymafejes bronzfibula, tűje hiányzik. A láb és az $U$ alakú kengyel díszített. A hagymafejek tagolt, bordázott díszítéssel csatlakoznak. $\mathrm{H}: 6,8 \mathrm{~cm}$. Sz: $4,5 \mathrm{~cm}$. M: 2,6 cm. Ltsz: 72.77.1. (V. t. 1.).

2. Üvegedény töredéke

Kihajló peremtöredék, fehér színü. H: $4,5 \mathrm{~cm}$. Sz: 2,6 cm. Fv: 0,3 cm. Ltsz: 72.77.2. (IV. t. 13.).

1971 októberében, földmunka során, újabb leletek kerültek elő:

3. Füles bögre

Kihajló peremü, ívelt, széles füllel, alacsony talpgyürüvel. Kaviccsal soványított, szürke. Szá: $9,9 \mathrm{~cm}$. Tá: 6,4 cm. M.: $15 \mathrm{~cm}$. Ltsz: 73.44.1. (IV. t. 4.).

82 Csizmadia 1998, 91. I. tábla 1.

83 Csizmadia 1998, 98. IX. tábla 3.

84 Lányi 1972, 70.

85 Berta Gyula tájékoztatását ezúton is köszönöm.

86 Honti Szilvia és Németh Péter Gergely terepbejárása. RRM A. 2509. KÖH 59362. lelöhely

87 Magyar Kálmán leletmentése, 1970 decemberében. RRM A. 943. A közlés jogának átengedését Magyar Kálmánnak ezúton is köszönöm. KÖH 19545. lelöhely. 
4. Füles pohár

Kihajló peremü, ívelt, széles füllel. Kaviccsal soványított, szürke. Szá: 7,1 cm. Fá: $5,2 \mathrm{~cm}$. M.: $11 \mathrm{~cm}$. Ltsz: 73.44.3. (IV. t. 5.).

5. Tál töredékei

Kihajló peremű, alacsony tál két töredéke. Kívülbelül árkolásokkal díszített, finoman iszapolt, szürke, szürkeszínű festéssel. H: 8 és 10,6 cm. Sz: 6,5 és $10 \mathrm{~cm}$. Fv: $0,7 \mathrm{~cm}$. M.: $3 \mathrm{~cm}$. Ltsz: 73.44.4. és 8 . (IV. t. 7. és 10.).

6. Aljtöredék

Pohár vagy bögre aljtöredéke. Kaviccsal sürün soványított, szürke. Fá: $3,4 \mathrm{~cm}$. M.: $6,2 \mathrm{~cm}$. Ltsz: 73.44.5. (IV. t. 11.).

7. Pohár töredékei

A kihajló peremen és az edénytesten árkolások futnak körbe. Finoman iszapolt, szürke. Fá: $4 \mathrm{~cm}$. M.: 5,2 cm. Ltsz: 73.44.6-7. (IV. t. 2-3.).

8. Kistál

Kihajló peremü, talpgyürüs, alacsony kistál. Finoman iszapolt, porózus, barna, barna festés nyomaival. Szá: $10 \mathrm{~cm}$. Tá: $4,8 \mathrm{~cm}$. M.: $3,4 \mathrm{~cm}$. Ltsz: 73.44.12. (IV. t. 13.).

9. Kistál

Kihajló peremü, alacsony kistál. Finoman iszapolt, porózus, barna, belül barna festés nyomaival. Pereme hiányos, külső felülete lepattogzott.

Szá: 9,9 cm. Fá: 3,8 cm. M.: 3,3 cm. Ltsz: 73.44.10. (IV. t. 8.).

10. Kistál

Kihajló peremü, talpgyürüs, alacsony kistál. Finoman iszapolt, porózus, barna, kívül barna festés nyomaival. Pereme kiegészített. Szá: $9,5 \mathrm{~cm}$. Tá: $4 \mathrm{~cm}$. M.: 3,3 cm. Ltsz: 73.44.11. (IV. t. 9.).

11. Tál

Kihajló peremü, a peremen árkolás fut körbe. Kaviccsal soványított, sötétszürke. Szá: $17,7 \mathrm{~cm}$. Fá: $11 \mathrm{~cm}$. M.: 5,3 cm. Ltsz: 73.44.13. (IV. t. 1.).

12. Fazék

Kihajló peremü, a perem alatt borda fut körbe. Kaviccsal soványított, barna foltos szürke. Szá: 12,4 cm. Fá: 7,4 cm. M.: 12 cm. Ltsz: 73.44.2. (IV. t. 6.).

13. Fazék

Vízszintesen kihúzott peremü, kaviccsal sürün soványított, barna foltos szürke. Szá: $10,4 \mathrm{~cm}$. Fá: $8,8 \mathrm{~cm}$. M.: 27,3 cm. Ltsz: 73.121.2. (V. t. 7.).

14. Érmék

Ltsz: 74.41.-3.

I. Constantinus

AE2 Siscia 315-316 RIC 15

H.: IOVI CONSERVATORI - Jupiter áll b. sceptrumot és globuson álló Victoriát tart, lábánál sas típus, // 'SIS. / A

I. Constantinus

AE2 Thessalonica 317-318 RIC 19

H.: IOVI CONSERVATORI - Jupiter áll b. sceptrumot és globuson álló Victoriát tart, lábánál sas típus, // $\cdot$ TS $\cdot \Gamma$.

I. Licinius

AE2 Siscia 313-315 RIC 4
H.: IOVI CONSERVATORI AVGG NN - Jupiter áll b. sceptrumot és globuson álló Victoriát tart, lábánál sas típus, // SIS / $\Delta$

A kerámiaedények párhuzamait a ságvári és somogyszili temetőben találjuk meg, a fazekak késő római telepek fordulnak elő. ${ }^{88} \mathrm{~A}$ kerámiaedények a 4 . századra jellemző formák. ${ }^{89} A$ festett kistálak viszont már a 2. század első felében is előfordulnak. ${ }^{90} \mathrm{Az} 1-2$. századra keltezhető az S-profilú tál (IV. t. 7. és 10.). ${ }^{91}$ A bronzfibula a Keller-Pröttner 3-4. típus $B$ változatához tartozik és 330-400 közé keltezhető. ${ }^{92} \mathrm{~A}$ fentiek alapján a sír a 4 . századra keltezető, valamint több szórványlelet is, de középső császárkori sírok is tartoztak a temetőhöz.

Az 1989. évi terepbejárás során, néhány kerámiatöredéket lehetett gyűjteni, ez alapján, feltételesen, a lelőhely a Kapoly-Tab müúttól délre is folytatódhat. ${ }^{93}$

\section{Táltöredék}

Behajló peremü tál töredéke, jól korongolt, csillámos felszínü, szürke. H: $4,4 \mathrm{~cm}$. Sz: $2,4 \mathrm{~cm}$. Ltsz: R.94.13.1.

2. Oldaltöredék

Enyhén ívelt, seprüdíszes, keményre kiégetett, szürke. H: $4,2 \mathrm{~cm}$. Sz: $3,3 \mathrm{~cm}$. Fv: 0,8 cm. Ltsz: R.94.13.2.

\section{Kaposkeresztúr}

1950-ben csontváz került elő, mellette „nagy tömeg" érme. ${ }^{94}$

\section{Kaposvár - Iszákdomb}

Sírlelet (edény, urna, merítőkanalak, 2 üvegpohár és üvegkarperec töredékei). A lelet Keszthelyre került. ${ }^{95}$

\section{Kaposvár - Répási mező}

Római temetőre utaló információ szerint, a biztosan meglévő telep mellett, temető is ismert, de további adat nincs. ${ }^{96}$

\section{Kaposvár - Klebersberg kollégium}

Költő László 2006. évi leletmentése során, késő római sír került elő. ${ }^{97}$

88 Ottományi 1990, 179.

89 Lányi 1972,70.

90 Bónis 1942, 22. és Csizmadia-Németh 2016, 125. Hasonló tálak Alsóbogáton kerültek elő. Uo. 124. és IV. t. 1-3.

91 K. Palágyi - Nagy 2000, 115

92 Pröttel 1988, 359. és 362

93 Németh Péter Gergely terepbejárása. RRM A. 130.

94 Kocztur 1964, 66. KÖH 26591. lelöhely.

95 Draveczky 1970, 17.

96 RRM A. 4157. KÖH 40025. lelőhely.

97 Ásatási dokumentáció KÖH 600/1204/2007. KÖH 43487. lelőhely. A környéken korábban elökerült leletek alapján temető és épület előkerülésének lehetőségéről tesz említést Bakay Kornél. Bakay 1975, 37. 


\section{Karád - Fehéregyháza}

Herk Mihály kapolyi lakos szerint több ízben kerültek elő sírok, 1963-ban Aurelianus érmét talált. ${ }^{98}$

\section{Karád - Köhát-dülő}

Herk Mihály szerint, az ismert római teleptől északra, kb. 500 m-re, vízvezeték ásásakor, római sírok kerültek elö. ${ }^{99}$

\section{Karád - Fürésztelep}

Herk Mihály szerint, a fürésztelep környékén, 1982ben, római sírt találtak. Kék színü gyöngyök tartoztak a sírhoz, amelyek azonban eltüntek. ${ }^{100}$

\section{Kánya - Kismalomi dülö} elő. ${ }^{101}$

1885 körül, Csösz György földjén, téglasír került

\section{Kercseliget - Temető}

1893-ban, sírásás közben, sírlelet került elö, korát a Magyar Nemzeti Múzeumba került, $7 \mathrm{db}$ II. Constantius és $1 \mathrm{db}$ Constans érme határozta meg. ${ }^{102}$ Az $1 \mathrm{~m}$ mély, csontvázas sírhoz eredetileg 10 érem tartozott. ${ }^{103}$ 1998-ban újabb sír került elő, szintén érmékkel. Barkóczy József (Kercseliget, József A. u. 5.) a községi temetö és a templom közötti feljáró létesítésekor, kb. $30 \mathrm{~cm}$ mélységben találta a sírt, amely É-D, vagy D-É tájolású lehetett. Az érmék a kar mellett helyezkedtek el. Leletmentés során csak néhány váztöredék került elö. A kisszámú megmaradt vázrész alapján a sírba egy felnőtt (23-x éves), de ezen belül pontosabban meg nem határozható korú, gracilis csontozatú nőt temettek. ${ }^{104}$

Az 1998-ban elökerült érmék:

II. Constantius

AE3 Siscia 355-358 RIC 372

H.: FEL TEMP REPARATIO - császár ledöfi az ellenséges lovast típus, // ASISD M

Iulianus caesar

AE3 Siscia 355-358 töredékes

H.: FEL TEMP REPARATIO - császár ledöfi az ellenséges lovast típus, // ]SI[

II. Constantius

AE4 355-358

H.: FEL TEMP REPARATIO - császár ledöfi az ellenséges lovast típus, M /

Iulianus caesar

AE4 355-358

H.: FEL TEMP REPARATIO - császár ledöfi az ellenséges lovast típus, M /

98 Draveczky Balázs leletmentése 1963-ban. RRM A: 959. KÖH 19552. lelöhely.

99 Herk 1985, 13. KÖH 19554. lelöhely.

100 Herk 1985, 13.

101 Wosinszky 1896, 779. és 1455. Bognár Zoltán helytörténész (Kapoly) szerint újabb sírok nem kerültek elö. Tájékoztatását ezúton is köszönöm.

102 Archaeológiai Értesítő 1893, 192. KÖH 47352. lelöhely.

103 Kocztur 1964, 75. Bakay 1975, 30.

104 Németh Péter Gergely leletmentése. RRM A. 1269. Barkóczy József leletbejelentését és az érmék átadását ezúton is köszönöm.
Constantinus dinasztia AE4 Keleti verde 347-348

H.: VOT / XX / MVLT / XXX típus

II. Constantius

AE3 355-358

H.: FEL TEMP REPARATIO - császár ledöfi az ellenséges lovast típus, M /

Constantius Gallus

AE3 Thessalonica 350-354 RIC 191

H.: FEL TEMP REPARATIO - császár ledöfi az ellenséges lovast típus, // SMTS E /

II. Constantius

AE3 355-358

H.: FEL TEMP REPARATIO - császár ledöfi az ellenséges lovast típus, M /

II. Constantius

AE3 Sirmium 351-358

H.: FEL TEMP REPARATIO - császár ledöfi az ellenséges lovast típus, //

ASIRM hátlap nagyon korrodált

II. Constantius

AE3 Siscia 351-358 RIC 352, 361

H.: FEL TEMP REPARATIO - császár ledöfi az ellenséges lovast típus, // ASISZ

II. Constantius

AE3 Siscia 351-358

H.: FEL TEMP REPARATIO - császár ledöfi az ellenséges lovast típus, // ASIS[

II. Constantius

AE3 Siscia 351-358 RIC 352, 361

H.: FEL TEMP REPARATIO - császár ledöfi az ellenséges lovast típus, // ASISZ

II. Constantius

AE3 Siscia 351-358 RIC 352, 361

H.: FEL TEMP REPARATIO - császár ledöfi az ellenséges lovast típus, // ]SISZ

II. Constantius

AE2 Nicomedia 348-351 RIC 60

H.: FEL TEMP REPARATIO - császár ledöfi az ellenséges lovast típus, // SMN

II. Constantius

AE3 351-358 hátlap nagyon rossz állapotú

H.: FEL TEMP REPARATIO - császár ledöfi az ellenséges lovast típus

Iulianus caesar

AE3 Siscia 355-358

H.: FEL TEMP REPARATIO - császár ledöfi az ellenséges lovast típus, // ]SIS[ M /

II. Constantius

AE3 351-358

H.: FEL TEMP REPARATIO - császár ledöfi az ellenséges lovast típus

II. Constantius

AE3 351-358 nagyon kopott

H.: FEL TEMP REPARATIO - császár ledöfi az ellenséges lovast típus

Az érmek alapján a temetkezéseket a 4. század 2. felére, 358 utánra tehetjük. 


\section{Lengyeltóti környéke}

Köosszárium, melynek pontos lelöhelye ismeretlen, a Magyar Nemzeti Múzeumba került, keltezése 2. század 2. fele - 3. század 1. fele. ${ }^{105}$

\section{Libickozma - A település déli vége}

Feltételesen római korinak meghatározott halomsíros temetö. ${ }^{106}$

\section{Mike}

Késő római temető, leletek nem kerültek be a kaposvári múzeumba. ${ }^{107}$

\section{Mosdós - Szőlőhegy}

1923-ban, a szőlőhegy északi lábánál, sírlelet került elő, téglákat is találtak. ${ }^{108}$

\section{Mázas tál}

Alacsony, széles tál, finoman iszapolt, barna. Barna színü mázzal díszített, mely, helyenként, zöld foltos. A máz, sávokban és foltokban, a tál oldalán és föleg az alján megmaradt. Peremén és belül bordadíszek és hullámvonal díszítés látható. Belsejében a szélén, körbefutó 16 , beljebb 4 , azonos pecsétlővel benyomott díszítést találunk. $A$ bepecsételés egyenetlen, néhány dísz halványan látszik, ezért a rajzon, csak 19 van ábrázolva. A pecsét Bellerophónt ábrázolja, Pégaszoszon lovagolva, szélén kör alakú díszítés sorral keretelve Szá: 36,6 cm. Fá: $27 \mathrm{~cm}$. M: 4,5 cm. Ltsz: 4300. (VII. t. 1. és 2. ábra.).

2. Üvegkorsó

Talpas korsó, kihajló, kettős peremmel, bordázott szalagfüllel, kobaltkék színü. Szá: $6,3 \mathrm{~cm}$. Fá: 8,4 cm. M: $35 \mathrm{~cm}$. Ltsz: 674. (VII. t. 2. és 3. ábra.).

3. Üvegpohár

Kúpos testü, fehér színü üvegpohár, perem alatt kettős vonallal, alatta vonalakkal és rovátkolásokkal sorok közötti, méhsejt alakú díszítéssel. Szá: 11 cm. M: 18 cm. Ltsz: 6805. (VII. t. 3. és 4. ábra.).

Az üvegkorsó a 4. század második felében készült, ${ }^{109}$ ugyanaz a keltezése az üvegpohárnak is. ${ }^{110}$ A mázas tál keltezése is megfelel ennek az időszaknak. ${ }^{111}$ A mosdósi tálhoz hasonló darabok kerültek elő a zengővárkonyi II. temető 3 . és 11 b. sírjából. ${ }^{112}$

\section{Mosdós - Pallavicini kastély}

A kastély építésekor szarkofágot találtak, a lelet további sorsa ismeretlen. ${ }^{113}$

\footnotetext{
105 MNM Ltsz.: 62.212.1. Fehér- Kovács 2017, 25-26. 106 Csizmadia-Németh 2016. 121. KÖH 59356. lelöhely. 107 RRM A. 7491

108 Kocztur 1964, 89. Bakay 1975, 34. és 24. kép. KÖH 47763. lelöhely.

109 Barkóczi 196., Kat. 486. Csizmadia 1998, 98., X. tábla.

110 Barkóczi 106., Kat. 76. Az egyedi díszítés párhuzamához I. Dévai 2012, 263.

111 Nádorfi, 1992, 50. Katalog 125.

112 Dombay 1957, 192-3., 207-9. V. t. 4. és XVII. t. 4

113 Kocztur 1964, 90. KÖH 47876. lelöhely.
}

\section{Mosdós - Nagy-hegy}

A Hármas-halomi-dülön, a Nagy-hegy északi, természetes nyúlványai találhatók, halomsír nem azonosítható. ${ }^{114}$

\section{Nagyberény}

1955-ben, Györe Péter ajándékaként, leletek kerültek be a kaposvári múzeumba, a leltárkönyv bejegyzése szerint, valószínüleg sírból származtak. ${ }^{115}$

\section{Füles bögre}

Kihajló peremü, ívelt füllel, talpgyürüs. Pereme sérült, finoman iszapolt, szürke foltos barna, függőleges besimításokkal. Szá: $6,8 \mathrm{~cm}$. Tá: $3 \mathrm{~cm}$. M: 13,2 cm. Ltsz: 55.31.1.1. (V. t. 8.).

2. Bronzkarperec

Kör keresztmetszetű, bordázott és stilizált kígyófejben végző karperec 2 töredéke. Tör H: 8,1 és 7,3 cm. Á: $0,1 \mathrm{~cm}$. Ltsz: $55 \cdot 31.1 .2$. (V. t. 9-10.).

A leletek között szerepelt még két egyforma pecsétgyűrü, jelenleg nem azonosíthatóak, leírásuk a leltárkönyvből:

3-4. Bronz pecsétgyürü

Kis női pecsétgyürü, a fejen hármas, gerezd-szerü bevéséssel. Á: $2 \mathrm{~cm}$. Ltsz: 55.31.1.3-4.

A füles bögre a 4. század második felére keltezhető. ${ }^{116} \mathrm{~A}$ karperec is hasonló időszakra tehető. ${ }^{117}$

\section{Nagyberény - Füzfa camping mellett}

1994-ben, téglasír került elő leletmentés során. ${ }^{118}$ A panzió melletti camping kialakításakor, emésztögödör ásása során került elő a sír (XI. tábla 3.). Mivel az ásást olyan személy végezte, aki korábban dolgozott a ságvári feltáráson, felhívta a panzió tulajdonának figyelmét a bejelentésre. ${ }^{119} \mathrm{~A}$ sír déli végében elökerült lábszárcsontot visszatemették. A sír az emésztögödör délnyugati falában került elő, $250 \mathrm{~cm}$ mélységben. A sírt fedő tegulák nagy része hiányzott és a lábszárcsontok kivételével, a csontok nem eredeti helyzetben voltak. Egy római érmét találtunk, a jobb combcsont felett, valamint üvegpohár töredékeit, melyek föleg a jobb karcsont magasságában helyezkedtek el. Ugyanitt vastag falú üvegedény töredékek is elökerültek. A mellékletek nem eredeti helyzetben voltak. A sírban néhány őskori (bronzkori) kerámiatöredéket is találtunk, valamint egy jellegtelen római kori oldaltöredéket. Az ÉK-DNY tájolású téglasír belül vakolva volt, az eredetileg jól megépített sírt csaknem teljesen kirabolták.

114 Németh Péter Gergely terepbejárása, 1997. RRM A. 1169. Ugyanakkor Marton Tibor, 2004-es terepbejárása során, halmot figyelt meg. A lelőhely újbóli bejárása szükséges. Csizmadia-Németh 2016. 123. KÖH 53374. lelőhely.

115 Kocztur 1964, 93

116 Ottományi 1991, 36

117 V. Péterfi, 1993, 81. és XXV. t. 7. 157. sír. A keltezéshez I. uo. 86 old.

118 Honti Szilvia és Németh Péter Gergely leletmentése. RRM A. 633. KÖH 47837. lelöhely.

119 Orsós Gézának és a panzió tulajdonosának, Ila Józsefné Landek Ibolyának ezúton is köszönöm a bejelentést, valamint a leletmentés során nyújtott segítséget. 

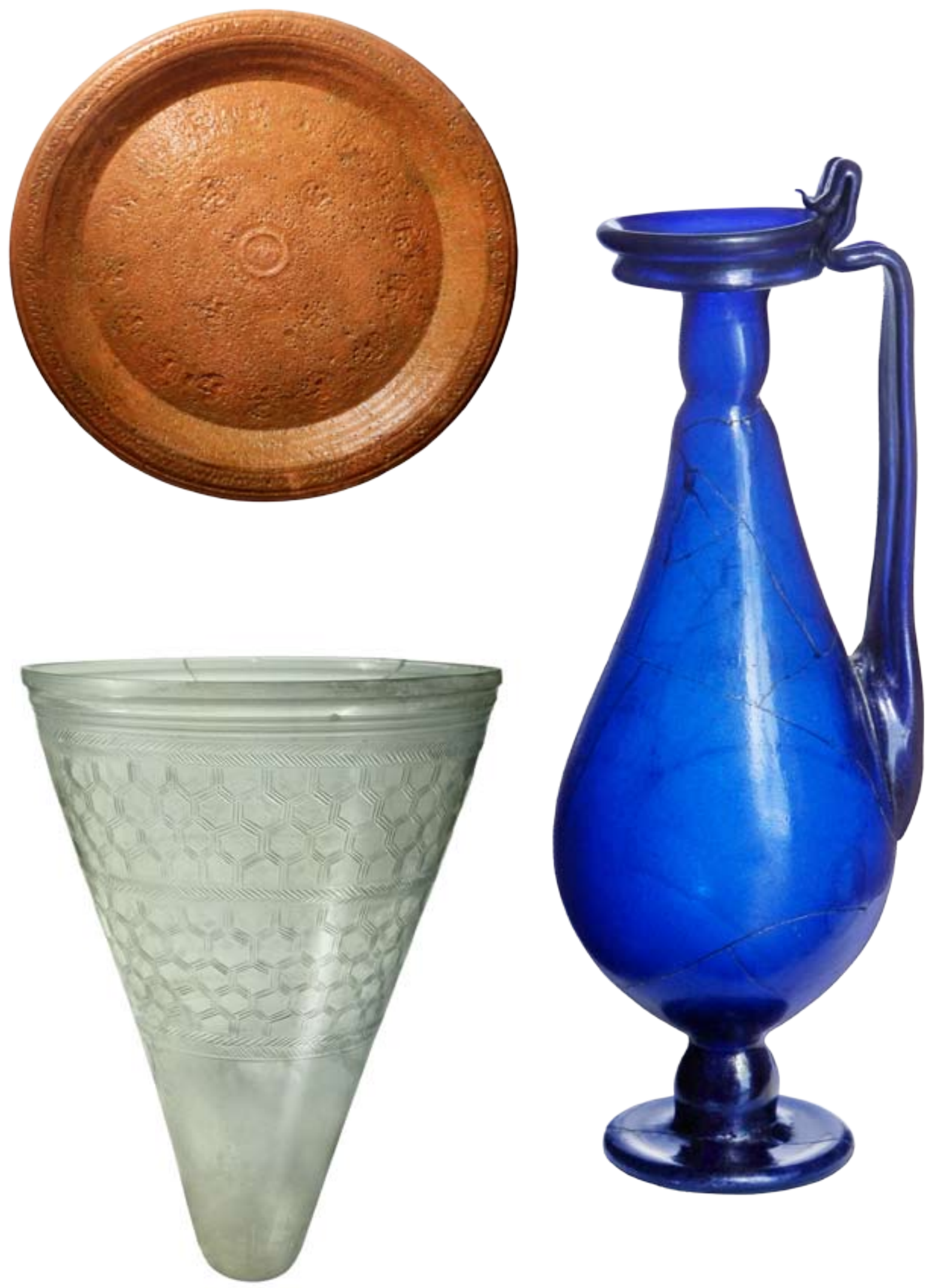

2-4. ábra. A mosdósi sírlelet 
1. Töredékes üvegpohár

Üvegpohár felső részének nagyobb töredéke és 13 kisebb oldaltöredék. Díszítetlen, zöldes fehér színü. A nagyobb töredék $\mathrm{H}: 9,5 \mathrm{~cm}$. Sz: $7,6 \mathrm{~cm}$. Fv: $0,1 \mathrm{~cm}$. R.2001.13.2. (V. t. 2. és 6.).

2. Üvegedény töredékei

Vastag falú, fehér színű oldaltöredék (42 db). Fv: 0,2 cm. R.2001.13.3. (V. t. 3-5.).

3. Érme

\section{Constans}

AE4 Siscia 347-348 RIC 195

H.: VICTORIAE DD AVGG Q NN - két Victoria szemben állva koszorúkat nyújtanak egymásnak típus, // 「SIS mezőben középen ág

4. Oldaltöredék

Ívelt, fekete színü oldaltöredék. H: 4,3 cm. Sz: 2,3 cm. Fv: 0,8 cm. Ltsz.: R.2001.13.5.

5. Tegulatöredék

Barna színü töredék. Tör. H: 20,5 cm. Tör. Sz: 14 cm. Fv: 6 cm. Ltsz.: R.2001.13.4.

A téglasír előtti földpadka lebontásakor, zsugorított csontvázas sír került elő (2. sír). A jobboldalára fektetett, mellékletnélküli váz koponyája hiányzott, minden bizonnyal a római sír kiásásakor semmisült meg. Sírfoltot és sírgödröt nem lehetett megfigyelni. Kora nem meghatározható. Az igen hiányos csontmaradványok embertani vizsgálata alapján a halott egy 40 évnél idősebb (40-x éves), gracilis csontozatú, valószínüleg alacsony termetü nő volt. Korát csak az erősen kopott fogak alapján lehetett becsülni.

Az emésztögödör sarkában gödör foltja jelentkezett (3. objektum). Bronzkori kerámiatöredékek mellett néhány római tegulatöredék és három jellegtelen római kori oldaltöredék került elő. A környékbeliek elmondása alapján, évekkel korábban, több, sír került elö, ezért a lelöhelyen több helyszínelés is volt, de újabb sír nem került elő. ${ }^{120}$

A töredékes üvegpohár a kúpos testű poharak közé tartozik, és a 4. század 2. felére keltezhető. ${ }^{121}$ A sírból előkerült érme datálása is megerősíti ezt. A másik üvegedény típusa nem meghatározható.

\section{Nagyberki - Szalacska}

1982-ben, csontvázas sírlelet került elő, $100 \mathrm{~cm}$ mélységből, sírfoltot nem lehetett megfigyelni (XI. tábla 2.). A felnőtt női váz jobbkarján sodrott bronzkarperec, balkarján hegyesedő végű vaskarperec volt. ${ }^{122}$ A leletek nem azonosíthatóak. A leírás alapján a temetkezésre a késő római időszakban kerülhetett sor. ${ }^{123}$

\section{Nagyberki - Szalacska- Szent-kúti-dülő}

Római kori halomsíros temető vagy utótemetkezés öskori halmokba. ${ }^{124}$

\footnotetext{
120 Kiss Tünde terepbejárása 1994, Költő László helyszínelése 2006 és Jankovich B. Dénes helyszínelése 2008. RRM A. 1384., 8374. és 9471 .

121 Csizmadia 1998, 95

122 Somogyi Múzeumok Közleményei 1982, 165. KÖH 47879. lelöhely. 123 V. Péterfi 1993, 86.

124 Csizmadia-Németh 2016. 126-127. KÖH 32370. lelöhely.
}

\section{Nemesvid - Iskolaudvar}

1974-ben, az iskolaudvar északi végénél, meszesgödör ásásakor, kb. $150 \mathrm{~cm}$ mélységböl, bögre került elő. Az edényt a következő évben, mint „síredénykét” átadták a kaposvári múzeumnak. Ez alapján, a lelet, temetkezéshez tartozott, bár a találók embercsontokról nem tettek említést. ${ }^{125}$

\section{Füles pohár}

Alacsony talpgyűrüs, finoman iszapolt, korongolásból származó korongolás nyomokkal. Ép, szürke. Szá: 6,1 cm. Tá: 4,7 cm. M: 10 cm. Ltsz.: R.94.22.1. (VI. t. 1.).

A bögre párhuzamait a ságvári és somogyszili temetőben találjuk meg, ${ }^{126}$ a 4 . századra jellemző forma. ${ }^{127}$

\section{Orci - Cseri-dülő}

Halomsíros temető. ${ }^{128}$

\section{Ordacsehi - Bugaszegi homokbánya}

A homokbánya északi falában, két sír került elö. ${ }^{129}$ $A z$ 1. sír erősen sérült volt, medencetájról vascsat került elő. Ettől $1 \mathrm{~m}$-re, délre volt a 2 . sír. A sírnak hiányzott a koponyája, egyébként sértetlen volt. Kulcscsontja körül és a nyaknál gyöngyök kerültek elö. A csontvázak nem azonosíthatóak a kaposvári múzeumban.

1. sír

1. Vascsat

Ép, ovális vascsat. A csattest, egy helyen, bordázott. H: 4,2 cm. Sz: 2,3 cm. V: 0,4 cm. A pecek H: 2,8 cm. A pecek Sz: 0,8 cm. Ltsz.: R.94.107.10. (VI. t. 3.).

\section{2. sír}

Gyöngysor

Fehér üveggyöngy (Á: $1 \mathrm{~cm})$, zöld és sárga színü gyöngy (Á: $0,6 \mathrm{~cm})$, kuboktaéder alakú ezüstgyöngy (Á: $0,3 \mathrm{~cm} . \mathrm{H}: 0,5 \mathrm{~cm}$ ), zöld színü, kerek üveggyöngy (Á: $0,2 \mathrm{~cm})$, henger alakú üveggyöngy $(\hat{A}: 0,1 \mathrm{~cm}$. $\mathrm{H}$ : $0,3 \mathrm{~cm}) .36 \mathrm{db}$ zöld és fekete színü üveggyöngy (Á: 0,1 cm). Ltsz.: R.94.107.11. (VI. t. 2.).

$A z$ 1. sír vascsatjához hasonló tárgy a Pécs-Málomi temető 2. sírjából került elő. ${ }^{130} \mathrm{~A}$ temető a népvándorlás korra, az 5 . század 1. felére keltezhető. ${ }^{131}$ A 2. sír gyöngyei késő római kori temetők jellegzetes mellékletei, a csákvári temető 58. sírjából kerültek elő hason-

\footnotetext{
125 Bakay Kornél helyszínelése 1975.04.18-án. RRM A. 6849. KÖH 47918. lelőhely. A közlés jogának átengedését Bakay Kornélnak ezúton is köszönöm.

126 Sz. Burger 1966, 123. Fig. 112. és Sz. Burger 1979, 47. Taf. 18. 1. 127 Lányi 1972.

128 Csizmadia-Németh 2016. 124-126. KÖH 47965. lelöhely.

129 Honti Szilvia leletmentése 1983-ban. RRM A. 132. A közlés jogának átengedését Honti Szilviának ezúton is köszönöm. Az 1986. évi terepbejárás során újabb sírok nem kerültek elö, csak egy kerámiatöredék. Honti Szilvia és Németh Péter Gergely terepbejárása. RRM A. 124. A sírok elökerülésének közelében késő római kori telepröl származó szórványleletek kerültek elő, több alkalommal. Ltsz: R.94.107.1-108.6.

130 Nagy 1993,95 . I. t. 1

131 Nagy $1993,97$.
} 
ló darabok. ${ }^{132}$ A kuboktaéder alakú gyöngy, üvegből készült párhuzama, a bátaszéki temető 76 . sírjából ismert és a kora népvándorlás kori, gót etnikum tárgyaként határozható meg. ${ }^{133} \mathrm{~A}$ fentiek alapján, a késő római leletek mellett lévő tárgyak már a temető kora népvándorlás kori keltezését támasztják alá.

\section{Ságvár - Ádándi út}

1949-ben, útépítéskor, több csontváz került elő, az egyikben, cserépkorsóban, II. Constantinus érméje volt. $^{134}$

\section{Ságvár - Somi út mentén}

1977-ben római sír került elő. ${ }^{135}$

\section{Ságvár - Tabán}

Az Ady u. nyugati részén, kora római, feltehetően hamvasztásos temető leletei ismertek. ${ }^{136}$

\section{Ságvár - Ady utca}

Az Ady u. keleti részén, földsír került elő. Az állítólag ÉNy-DK tájolású sír melléklete egy szürke, besimított, egy fülü korsó volt, mely az 5 . század első felére keltezhető. ${ }^{137}$ 1992-ben, szintén az Ady utcában, valószínűleg másodlagos helyzetben lévő, lelet és fedő nélküli szarkofág került elö. ${ }^{138}$ 2014-ben, a lelőhelytől északra, római érmék és tárgyak kerültek elő.

\section{Ságvár - Tömlöchegy}

Az ismert temető területén, ${ }^{139}$ 1974-ben, újabb téglasír került elő, „boltívesen kirakott kamrával”. ${ }^{140}$ A sírt gyermekek bolygatták meg és a leletek Ernyés István ajándékaként kerültek be a kaposvári múzeumba.

Mellékletek:

1. Bronz övcsat

Ovális csat rovátkolt pecekkel. A töredékes csattesten felerősítő bronzszegecs megmaradt. $\mathrm{H}: 1,8 \mathrm{~cm}$. Sz: 1,4 cm. Ltsz.: R.2004.35.1. (VIII. t. 22. és 23.).

2. Bronzkarika

Ellapított, ép bronzkarika Á: $1,8 \mathrm{~cm}$. V: $0,1 \mathrm{~cm}$. Ltsz.: R.2004.35.2. (VIII. t. 14.).

3. Bronzkarika

Kör keresztmetszetű bronzkarika. Á: $2 \mathrm{~cm}$. V: 0,1 cm. Ltsz.: R.2004.35.3. (VIII. t. 15.).

132 Salamon-Barkóczi 1971, 55. Abb. 10

133 V. Péterfi 1993, 62. X. tábla és 85.

134 Szilágyi Zoltán útépítő munkás levele. RRM A. 4786. A leletek nem kerültek be a kaposvári múzeumba. KÖH 48138. lelöhely.

135 Tóth Endre helyszínelése. KÖH 600/2063/2005. KÖH 51160. lelöhely.

136 Tóth 2009, 24.

137 Tóth 2009, 37. és 8 . tábla és Tóth 2011 , 305. és 4 . tábla 1 . KÖH 51158. lelöhely.

138 Németh Péter Gergely leletmentése. RRM Adattár 434. Szórványként kevés római kerámiatöredék is elökerült. Ltsz.: R.2004.38.1-5

139 Sz. Burger 1966. Az újabb kutatási eredményekre I. Tóth 2009, 36-37. és Schmidt 2000. KÖH 48122. lelöhely.

140 Bárdos Edith és Magyar Kálmán helyszínelése 1978-ban. A közlés jogának átengedését Bárdos Edithnek és Magyar Kálmánnak ezúton is köszönöm. RRM A. 431. és 4845

\section{Bronztárgy}

Bronzcsüngö töredéke. $\mathrm{H}: 2 \mathrm{~cm}$. Sz: 1,7 cm. V: 0,1 cm. Ltsz.: R.2004.35.4. (VIII. t. 16.).

5. Gyöngy

Fekete színü üveggyöngy. Á: $0,4 \mathrm{~cm}$. Ltsz.: R.2004.35.5. (VIII. t. 25.).

6. Üvegedény töredékei

Zöldes fehér színű üvegedény töredékei (60 db). V: 0,2 cm. Ltsz.: R.2004.35.6. (VIII. t. 1-3.).

7. Vastárgy

Karikában végződő, ellapított vastárgy. A karikában kerek, töredékes vasdarab maradt meg. $\mathrm{H}: 4,1 \mathrm{~cm}$. V: 0,3 cm. Ltsz.: R.2004.35.7. (VIII. t. 26.).

8. Vaskés töredékei

Egyenes hátú kés töredékei ( $5 \mathrm{db}$ ). A nyéltüske hiányzik. Három, kisebb töredék bizonytalanul tartozik hozzá. V: 0,7 cm. Ltsz.: R.2004.35.8. (VIII. t. 17-18.).

9. Vastárgy

Kör keresztmetszetű vastárgy töredékei (4 db). Vége összeszűkül. Á: $1 \mathrm{~cm}$. Ltsz.: R.2004.35.9. (VIII. t. 6-8. és 19.). Esetleg az előző kés nyele lehetett.

10. Bronz övcsat

Négyzetes, sarkain kiemelt, árkolt csat. A pecek rovátkolt. $A$ négyzetes csattest szélei árkoltak. Két felerősítő bronzszegecs megmaradt. $\mathrm{H}: 3,6 \mathrm{~cm}$. Sz: $3,2 \mathrm{~cm}$. V: 0,2 cm. Ltsz.: R.2004.35.10. (VIII. t. 4.).

11. Vasdísz

Három csavart, egy félköríves vasdísz (4 db). V: 0,1 cm. Ltsz.: R.2004.35.11. (VIII. t. 9-11. és 20.).

12. Bronzfibula

Hagymafejes fibula töredéke. A bordázott kengyel hiányos, a tütartó díszített. Tüje hiányzik. H: 5,4 cm. Sz: 0,6 cm. M: 1,1 cm. Ltsz.: R.2004.35.12. (VIII. t. 5.).

13. Bronztárgy

Profilált fejü, töredékes bronzveret. Á: $1,9 \mathrm{~cm}$. M: $1,5 \mathrm{~cm}$. V: 0,2 cm. Ltsz.: R.2004.35.13. (VIII. t. 23.).

14. Bronztárgy

Félgömb alakú, töredékes bronztárgy. $\mathrm{H}: 2,4 \mathrm{~cm}$. Sz: 2 cm. Ltsz.: R.2004.35.14. (VIII. t. 21.).

15. Üvegkarperec töredékei

Kék színü üvegkarperec töredékei (30 db). V: 0,9 cm. Ltsz.: R.2004.35.15. (VIII. t. 12-13.).

16. Érmék

Ltsz.: R.2004.34.1-24.

Constantius Gallus

AE2 351-354

$\mathrm{E}: \Delta /$

H.: FEL TEMP REPARATIO - császár ledöfi az ellenséges lovast típus

Gratianus AE3 Siscia 367-375 RIC 14c/16-17

H.: GLORIA ROMANORVM - császár áll labarumot tartva és lenyom egy ellenséget típus, // ГSISC $M / F$ vagy $P$, felette *

II. Constantius

AE3 351-358

H.: FEL TEMP REPARATIO - császár ledöfi az ellenséges lovast típus 
Valens

AE3 Siscia 364-367 RIC 7b/5-7

H.: SECVRITAS REI PVBLICAE - Victoria megy balra, kinyújtott kezében koszorút, vállán pálmaágat tart típus, A felett * /

Valens

AE3 364-378

H.: SECVRITAS REI PVBLICAE - Victoria megy balra, kinyújtott kezében koszorút, vállán pálmaágat tart típus nagyon kopott

II. Constantius

AE3 Thessalonica 355-358 RIC 208

H.: FEL TEMP REPARATIO - császár ledöfi az ellenséges lovast típus, // SMTS $\triangle \mathrm{M}$ /

II. Constantius AE4 Siscia 337 RIC 263

H.: GLORIA EXERCITVS 1 jelvényes típus (két katona között 1 katonai jelvény) // ]SIS*

Valens

AE3 Aquileia 364-367 RIC 9b/3

H.: SECVRITAS REI PVBLICAE - Victoria megy balra, kinyújtott kezében koszorút, vállán pálmaágat tart típus, // SMAQ[ B, alatta pont /

II. Constantius

AE4 Siscia 351-358

H.: FEL TEMP REPARATIO - császár ledöfi az ellenséges lovast típus,

// ]SIS[ nagyon kopott

Valens

AE3 Thessalonica 364-367 RIC 18b/?

H.: SECVRITAS REI PVBLICAE - Victoria megy balra, kinyújtott kezében koszorút, vállán pálmaágat tart típus, // TESA /?

Constantinus dinasztia

AE4 335-364

Nagyon kopott, H.: semmi nem látszik

II. Constantius

AE4 351-358 nagyon kopott

H.: FEL TEMP REPARATIO - császár ledöfi az ellenséges lovast típus

II. Constantius

AE4 351-358 nagyon kopott

H.: FEL TEMP REPARATIO - császár ledöfi az ellenséges lovast típus

Iulianus caesar

AE4 358-361 nagyon kopott, töredékes

H.: SPES REI PVBLICAE - katona áll szemben, lándzsát és gömböt tart típus

II. Constantius

AE4 Siscia 335-336 RIC 254

H.: GLORIA EXERCITVS - 1 jelvényes típus (két katona között 1 katonai jelvény) // ГSIS

Valentinianus dinasztia

AE3 nagyon kopott, töredékes

H.: SECVRITAS REI PVBLICAE - Victoria megy balra, kinyújtott kezében koszorút, vállán pálmaágat tart típus

Constantinus dinasztia

AE4 335-340 erősen töredékes, kopott

H.: GLORIA EXERCITVS - 1 jelvényes típus (két katona között 1 katonai jelvény)
Constantinus dinasztia

AE4 347-348 erösen kopott, töredékes

H.: VICTORIAE DD AVGG Q NN - 2 Victoria áll szemben egymással koszorúkat tartva típus

I. Valentinianus

AE3 Siscia 364-375

H.: GLORIA ROMANORVM - császár áll labarumot tartva és lenyom egy ellenséget típus, // ]SISC[ ? / ?

Valentinianus dinasztia

AE3 364-378 félbe törött érem

H.: SECVRITAS REI PVBLICAE - Victoria megy balra, kinyújtott kezében koszorút, vállán pálmaágat tart típus

I. Valentinianus

AE3 Siscia vagy Aquileia 364-375

H.: SECVRITAS REI PVBLICAE - Victoria megy balra, kinyújtott kezében koszorút, vállán pálmaágat tart típus, D /

Valentinianus dinasztia

AE3 364-378 1/3-d érem

H.: GLORIA ROMANORVM - császár áll labarumot tartva és lenyom egy ellenséget típus

4. századi törött kisbronz és 4. századi kisbronz töredékei

A töredékes bronzfibula a Keller-Pröttner 3-4. típus B változatához tartozik és 330-400 közé keltezhető. ${ }^{141}$ Az üvegkarperec (VIII. t. 12-13.) a késő római időszakban készült. ${ }^{142} \mathrm{Az}$ üveggyöngy (VIII. t. 25.) késő római temetőkben fordul elő. ${ }^{143} \mathrm{~A}$ bronz övcsatok (VIII. t. 4. és 22. és 24.) is hasonló környezetben fordulnak elő. ${ }^{144}$ A többi tárgy pontos keltezése nem lehetséges és néhány tárgy esetében a római korba sorolás is kétséges. A sír helyszínelésének feljegyzésében aranytárgy is szerepel. ${ }^{145} \mathrm{~A}$ temetkezésre a 4 . század végén kerülhetett sor.

1986-ban, a Tömlöchegyen, sírrablásból származó embercsontok kerültek elö, egyéb lelet nélkül. ${ }^{146} 2014$ ben, a római temető északnyugati részén, nagyobb partfalomlás történt, ebben és a lemosódásban, több téglatöredék és vaskarika került elő. A partfal helyreállításakor lelet nem került elő. A lemosódástól keletre, fémkeresővel, több római érmét találtunk. Az omlás helyétől délre, a szántásban több római kori sírtéglát és megmunkált mészkőtöredéket lehetett megfigyelni, sírhelyet nem. ${ }^{147}$

\section{Segesd - Bertalanpuszta}

A nagykiterjedésű római telepen, vagy annak közelében, 1974-ben, sír került elő. ${ }^{148}$

141 Pröttel 1988, 359. és 362

142 R. Facsády 2009, 46.

143 Gaál 1979, 40.

144 Lányi 1972. Abb. 52. 24. típus és Abb. 53. 34. típus.

145 1974-ben, a sírleletek megszerzése után, római aranyfülbevaló és újkori aranytárgy került be a múzeumba (gyarapodási naplószám: 74/375-6.). A fülbevaló feltételesen tartozhatott a sírleletek közé.

146 Honti Szilvia és Németh Péter Gerely leletmentése, RRM A. 170. 147 Németh Péter Gergely helyszínelése. RRM A. 5843.

148 A római kisbronzok, szürke edénytöredékek és embercsontok nem kerültek be a kaposvári múzeumba. RRM A. 7930. KÖH 47433. lelöhely. 


\section{Siófok - Kápolnai dülő}

Szarkofág fedele került elö, mely vörösberényi köböl készült. Kuzsinszky Bálint már nem találta, Sági Károly szerint maga a dülő sem azonosítható. ${ }^{149}$

\section{Siófok - Kavicsbánya}

1950-ben elökerült leletek, urna, 2 mécses, 2 érme (az egyik Domitianus), bronz pajzsdudor és vastárgyak) alapján Radnóti Aladár szerint temető lehetett itt. ${ }^{150}$

\section{Somogyaszaló - Deseda-erdő}

Halomsíros temetö. ${ }^{151}$

\section{Somogydöröcske - Görbedülő}

Késő római kori temetőre és telepre utaló leletek, leletek nem kerültek be a kaposvári múzeumba ${ }^{152}$

\section{Somogyjád - Apánkai-erdő \\ Halomsíros temetö. ${ }^{153}$}

\section{Somogyjád - Szállási-dülő}

1964-ben, útépítés során került elő, „mintegy 300 db téglából habarccsal épített házalakú sír", elmondás alapján a váz mellett érmék, vaskés, kerámia és több üvegedény volt. A leletek nem kerültek be a kaposvári múzeumba. ${ }^{154}$

\section{Somogyszil - Csárdavölgyi-dülő}

$\mathrm{Az}$ ismert temetőtől $\mathrm{I}^{155} \mathrm{~kb}$. 500 méterre, délnyugatra került elő egy téglasír, valószínüleg egy újabb sírcsoporthoz tartozik. ${ }^{156} \mathrm{~A}$ publikációjában a lelöhely pontatlanul szerepel, a valóságban a temető a SomogyszilVárong úttól északra található és nem a Dögkúti-dűlö, hanem a Csárdavölgyi-dülö területére esik. A lelöhely a 1975. évi helyszínelés vázlatrajzán már pontosan szerepel. A sír tájolása Ny-K, hossza $180 \mathrm{~cm}$, mélysége $70 \mathrm{~cm}$ (XI. tábla 1.). A felső, nyeregtetős részt $10 \mathrm{db}$ téglából alakították ki, átlagos méreteik: $52 \times 37 \times 6 \mathrm{~cm}$. A padozattéglákat nem számolva, összesen 26 téglából építették meg a sírt, $0,8 \mathrm{~cm}$ vastag vakolás borította a téglákat. Két téglán alfa-jelre emlékeztető, egy téglán átlósan fektetett kereszt volt. Egy $60 \times 60 \times 6 \mathrm{~cm}$ méretủ téglán három koncentrikus körbe foglalt kereszt volt. A téglák a kaposvári múzeum gyüjteményében nem azonosithatók, kérdéses, hogy egyáltalán bekerültek-e. Szintén nem azonosítható a sír betöltéséböl

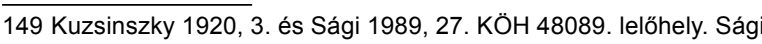
Károly említi még a vasútállomásnál lévő temetőt is, leírása azonban a Rádióállomásnál előkerült avar temetőre érvényes. Sági id. mü. 26-27.

150 MNM A. 17.S.I. Kocztur 1964, 124. A területen Honti Szilvia végzett leletmentést, római lelet nem került elö. KÖH 51171. és 45330. lelőhely.

151 Csizmadia-Németh 2016. 127-130. KÖH 45227. lelöhely. Az 1. halomból származó, egy darab égett végtagcsont alapján a halott nemét és életkorát nem lehetett becsülni.

152 Draveczky 1965, 74.

153 Csizmadia-Németh 2016. 131-1134. KÖH 19860. lelöhely.

154 Draveczky 1965, 71. KÖH 49059. lelöhely.

155 Sz. Burger, 1979. KÖH 19948. lelöhely.

156 Bakay Kornél-Bárdos Edith leletmentése 1975-ben. A közlés jogának átengedését Bárdos Edithnek és Bakay Kornélnak ezúton is köszönöm. RRM A. 709. gyüjtött növényi minta (magvak és kalászosok) sem. A sírban két női váz volt, egy felnőtt nő és egy gyermek. A felnőtt váz jobb karja eredetei helyzetben volt, a gyermekváz alatt, két vastárgy (gyürü és karperec) (4. sz. melléklet), nem eredeti helyzetböl került elö, így nem eldönthető, hogy melyik vázhoz tartozott. A felnőtt váz a medencecsonttól lefelé teljesen bolygatatlan volt, melléklet nem került elő. A gyermekcsontváz, a koponya és a bordák kivételével, érintetlen volt. A koponya arccsontjai összetörtek, de eredeti helyzetben voltak. A koponya alatt és mellett 5 hajtű került elő (1. sz. melléklet). A jobb felkarcsont felett érme került elő (2. sz. melléklet). Jobb csuklón aranyozott ezüst karperec volt (3. sz. melléklet). A medence felett vasdarab, esetleg vascsat feküdt (5. sz. melléklet). A sírból előkerült még egy kerámiatöredék is (6. sz. melléklet).

1. Hajtü

5 ezüst hajtü $13 \mathrm{db}$ töredéke. 2 gömbfejü, és 3 bordázott díszítésü, zöld színü üvegbetétel. A legépebben megmaradt hajtük $H: 6,3$ és $5,7 \mathrm{~cm}$. A fej Á: 0,8 és 0,5 cm. Ltsz.: R.2004.1.6. (VI. t. 4A-E. és 6. ábra.).

2. Érme

Ltsz.: R. 2004.1.1. Valentinianus dinasztia AE3 364-378 nagyon kopott, elvékonyodott H.: GLORIA ROMANORVM - császár áll labarumot tartva és lenyom egy ellenséget típus

3. Aranyozott ezüst karperec

Kör keresztmetszetü, egymásra futó végü karperec. Á: 4,5 cm. V: 0,2 cm. Ltsz.: R.2004.1.5. (VI. t. 5. és 5. ábra.).

4. $2 \mathrm{db}$ vaskarika

Ép vasgyűrü. Á: 2,5 cm. V: 0,2 cm. Ltsz.: R.2004.1.3. (VI. t. 6.). Kör keresztmetszetű vaskarperec 5 töredéke, szövetmaradvánnyal. V: $0,1 \mathrm{~cm}$. Ltsz.: $\mathrm{R}$. 2004.1.4. (VI. t. 7.).

5. Vastárgy

Vasdarab, esetleg vascsat, a múzeumban nem azonositható.

6. Fültöredék

Finoman iszapolt, világosbarna. $\mathrm{H}: 2 \mathrm{~cm}$. Sz: 9,3 cm. Fv: 0,6 cm. Ltsz.: R.2004.1.2.

\section{Vakolat}

Szabálytalan alakú vakolatdarab. H: 10,6 cm. Sz: $1,5 \mathrm{~cm}$. V: 0,9 cm. Ltsz.: R.2004.1.7.

A sírban lévő gömbfejü hajtük (VI. t. 4A-B.) bronzból készült változata, 4. századi sírból került elő. ${ }^{157}$ A bordázott díszítésü, üvegpaszta betétes hajtűk (VI. t. 4C-E.) hasonló formában, de más anyagból, a Bartus 4. típusba tartoznak, és már a 3. században megjelennek. ${ }^{158} \mathrm{Az}$ aranyozott ezüst karperec a nyitott karperec típusba tartozik és Nagyberki-Szalacskán már a 3. század 2. felétől előfordul. ${ }^{159}$ A vaskarperec és vasgyürü késő római kori sírokban fordul elő. ${ }^{160} A$ sírban

157 R. Facsády 2009, 85. Tárgykatalógus 329.

158 Bartus 2006, 196.

159 R. Facsády 2009, 47

160 V. Péterfi 1993, 87. 
lévő, nagyon kopott érme alapján, a temetkezésre a 4. század végén kerülhetett sor.

1990. évi terepbejárás rögzítette a temetőhöz tartozó telep (villa) helyét. ${ }^{161}$ Ezen a bejáráson, a temető területén, néhány római kori szórvány került elő. Ugyancsak kevés szórványlelet került elő egy újabb bejáráson is. ${ }^{162} \mathrm{~A}$ terepbejárásokon két érme került elő, Itsz.: R.2004.3.7. és R. 2004. 4. 6.

\section{Valentinianus dinasztia}

AE3 364-378 nagyon kopott

H.: SECVRITAS REI PVBLICAE - Victoria megy balra, kinyújtott kezében koszorút, vállán pálmaágat tart típus II. Licinius

AE3 Siscia 319 RIC 70

H.: VICTORIAE LAETAE PRINC PERP - 2 szemben álló Victoria pajzsot tart VOT / PR felirattal típus, // ASIS.

\section{Somogyszil - Kálvária}

A Kálvária mellől lovassír került elő, melyet a szarmata korba soroltak, az újabb kutatás szerint azonban provinciális kori. ${ }^{163} \mathrm{~A}$ budaörsi párhuzama alapján a keltezése a 2. század 1. fele. ${ }^{164}$

\section{Somogyvár - Bréza-erdő}

Halomsíros temető. ${ }^{165}$

\section{Somogyvár - Pénzestábla}

1855-ben, faültetés során, téglasír került elő. A „háztetőformára rakott”, $3 \mathrm{~m}$ mély sírban, a csontváz mellett, 3 gombos bronzfibula, üvegcsésze, üvegtöredékek, egy elkorhadt faszelence mellett, „ruhával bekötve”, 52 Constantinus érme volt. ${ }^{166}$ A csontvázból csak egy fog őrződött meg. A leletek Széchenyi Dénes grófhoz, a sírtéglák egy része a kaposvári Múzeumi Társulat tulajdonába kerültek. ${ }^{167}$ Jelenleg semmilyen tárgy sincs a kaposvári múzeum gyűjteményében. ${ }^{168}$

161 Honti Szilvia - Helmut Bender - Visy Zsolt és Németh Péter Gergely terepbejárása. RRM A. 144.

162 Németh Péter Gergely terepbejárása. RRM A. 102

163 Mráv 2007, 2424. 11a-b. kép. KÖH 49090. lelöhely. A lelet korszakba sorolása eleve problémás volt, az első említésekor az őskorba, vagy a honfoglalás korba keltezték. Archaeologiai Értesítő $1904,437$.

164 Mráv 2007, 241-243.

165 Csizmadia-Németh 2016. 134-136. KÖH 44355. lelöhely. Az 1 halomban eltemetett halott hamvainak embertani vizsgálatából mindössze annyit lehetett megállapítani, hogy a sírba egy nagy valószínüséggel felnőtt korú (23-x éves) egyént temettek. A halott nemének meghatározásához szükséges bélyegek közül egy sem volt vizsgálható. A 2. halomba ugyancsak egy meghatározhatatlan nemü, felnőtt korú (a koponyavarratok elcsontosodása alapján 23-59 éves) egyént temettek.

166 Archaeologiai Értesítő 1886, 42. A leletmentést végző Lipp Vilmos leírja, hogy a Pénzestábla onnan kapta az elnevezését, hogy nagyon sok római érmét találtak itt. A gróf birtokába is sok érme („Constantinus-félék”) került.

167 Melhárd 1882, 55. Melhárd leírja, hogy a sír „állítólag” 2,5 m hoszszú és $1,5 \mathrm{~m}$ széles volt.

168 Koctur Éva két sírról tesz említést, de csak egy sír került elő. Kocztur 1964, 128.

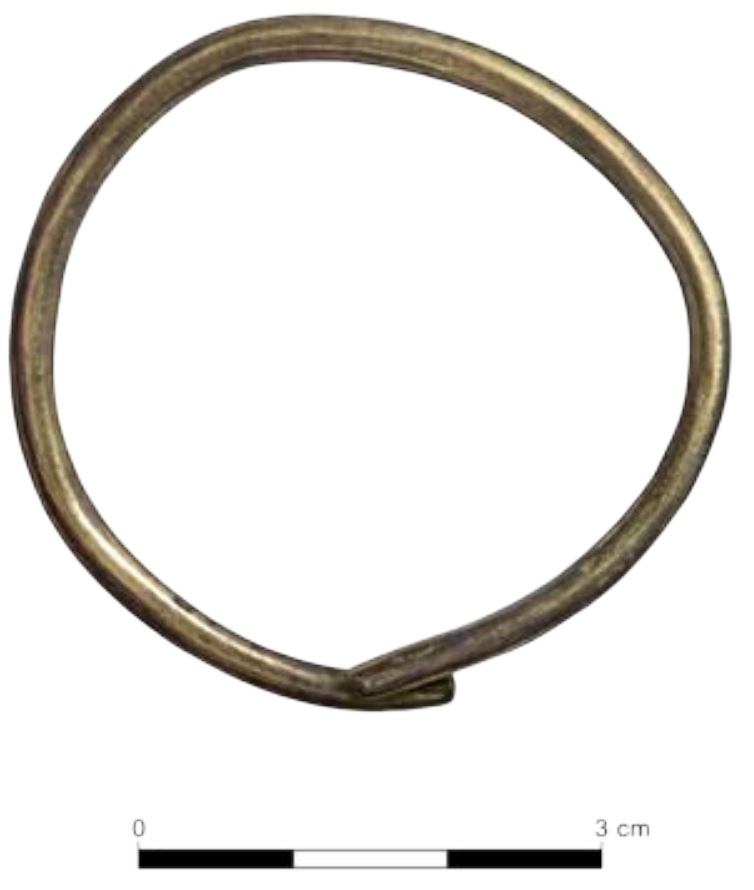

5. ábra. A somogyszili aranyozott ezüst karperec

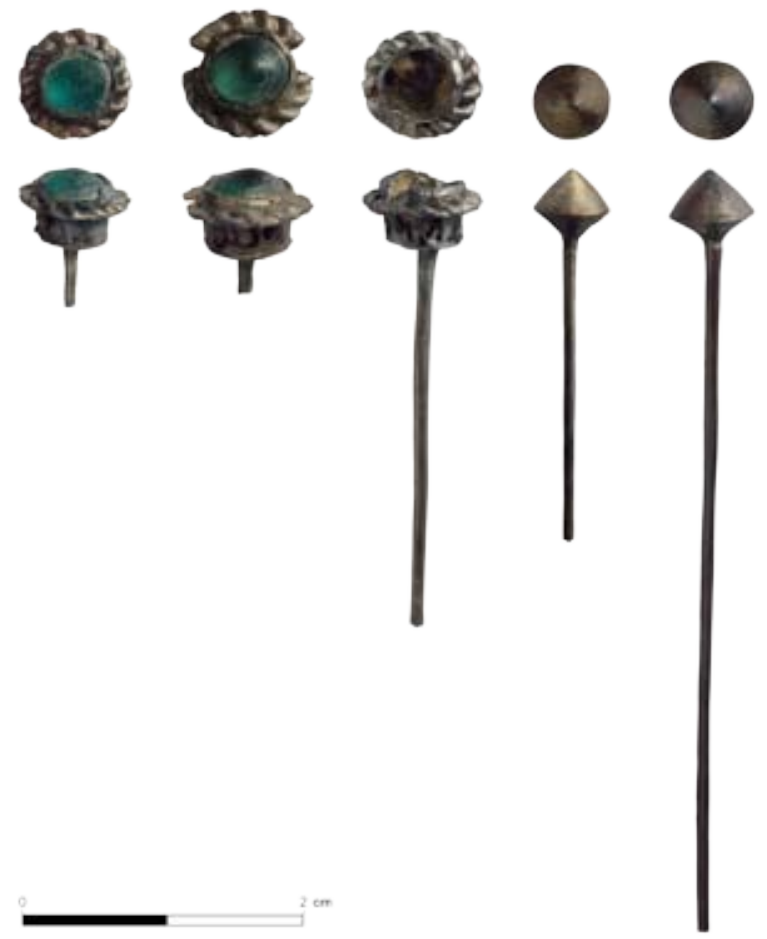

6. ábra. Hajtük a somogyszili sírból 


\section{Somogyvár - Resterica II. lelőhely}

3 római szarkofág került elő, a felszíni leletek alapján több téglasírt is rejt a föld. ${ }^{169}$

\section{Somogyzsitfa - Szőcsénypuszta}

1885-ben téglasír került elö, a középkori földvártól délnyugatra. A sírhoz $37 \mathrm{db}, 45 \mathrm{~cm}$ hosszú, $32 \mathrm{~cm}$ széles és $6 \mathrm{~cm}$ vastag, részben vakolt tégla tartozott. ${ }^{170}$ A sírban két csontváz volt, a mellékletek (balsamarium, ezüstérmék, bronz- és vastárgyak) a Magyar Nemzeti Múzeumba kerültek.

\section{Szántód - Szántódpuszta}

A Majortól keletre, a Kápolnától mintegy 200 lépésre, az országúton, 1898-ban téglasír került elő. ${ }^{171} \mathrm{~A}$ sírban két érme volt (az egyik I. Valentinianus), valamint egy edény. ${ }^{172}$ Talán ugyanebböl a sírból kerültek leletek a Magyar Nemzeti Múzeumba: bronzfibula, bronzcsat és 39 érme. ${ }^{173}$ Kuzsinszky Bálint a sírleleteket a 4. század 2. felére keltezi. ${ }^{174}$ Piller Dezső, helyi hagyományokra hivatkozva, említ további római sírokat a Plébániakertből, ${ }^{175}$ Szántódpusztáról ${ }^{176}$ és az Állási-dűlőből is. ${ }^{177}$ Nem elképzelhetetlen, hogy a hagyomány részben, az 1898-ban előkerült szántódpusztai sírra vonatkozik.

\section{Szólád}

A községtől keletre, 1903-ban, temetőből származó leletek kerültek elö, melyek elkallódtak. A vegyes rítusú temető leletei mellett telepről származó tárgyak, valamint őskori leletek is voltak. ${ }^{178}$

\section{Szólád - Berek}

A pálinkaházi csapástól délre, 1957-ben, kora római urna került elő szántás közben, mellette vékonyfalú edény volt. ${ }^{179}$

\section{Szólád - Major}

Az Öszödi u. 5. szám alatti ház kertjéből, sírokból származó leletek, Ősz József ajándékaként kerültek a kaposvári múzeumba. ${ }^{180} \mathrm{~A}$ tárgyak mellett néhány kalcinált embercsontok is bekerült a múzeumba. Ez alapján talán hamvasztásos temetkezés is volt Szóládon, bár a tárgyakon nem figyelhető meg másodlagos égésnyom. A kisszámú hamvasztott csontmaradvány

169 A temetető anyagát Hajdú Ádám dolgozza fel. KÖH 47997. lelöhely.

170 Archaeologiai Értesítő 1887, 434-435. Kocztur 1964, 140

171 Archaeologiai Értesítő 1899, 74. és Kuzsinszky 1920, 13.

172 Kuzsinszky 1920, 14. ábra. és Sági 1983, 19. rajz. Ebben a tanulmányban: 10. t. 2. Hasonló edény a somogyszili temető 38 . sírjából került elö. Sz. Burger 1979, 31. Taf. 8. 7. és Taf. 29

173 Ltsz: MNM. 116.1898.1-3.

174 Kuzsinszky 1920, 13.

175 RRM A. 5114. 38. oldal.

176 RRM A. 5114. 38. oldal.

177 RRM A. 5114. 38. oldal. KÖH 49880. lelöhely.

178 Kolbach B. 1903. és Kuzsinszky 1920, 19. és 22. ábra.

179 A vékony falú edény összetört, a másik edény Antal Attila magángyüjteményébe került. Ságí-Cséby 1993, 76.

180 Ságy-Cséby 1993, 75. Ugyanott említés történik a 17. szám alatti ház kertjéböl előkerült két kora római urnáról is, de ez az adat téves. Ösz Józsefnek a leletek beadását és az utóbbi adat tisztázását ezúton is köszönöm. alapján a sírban egy felnőtt korú (23-x éves) nő nyugodott. A halott nemének megállapításánál a csigolyák kis mérete nyújtott támpontot. 2015-ben, régészeti megfigyelés során, újabb lelet nem került elő. ${ }^{181}$

\section{Bronztükör}

Kör alakú, oldalán eredetileg 52 lyukkal. Nyele hiányzik, mindkét oldala koncentrikus körökkel díszített. Á: 7,8 cm. V: cm. Ltsz.: R.94.58.6. (IX. t. 1. és 7. ábra.).

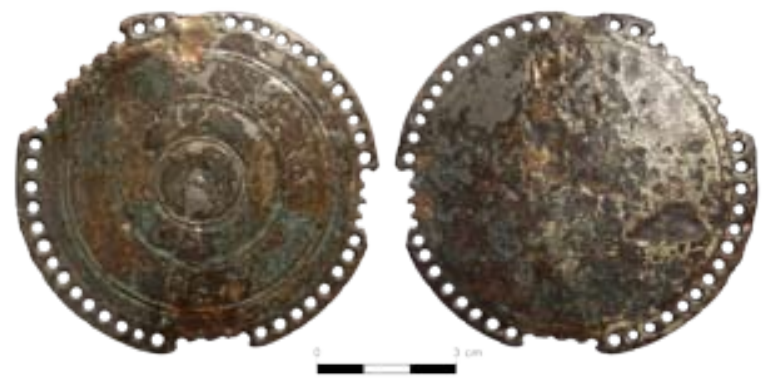

7. ábra. A szóládi tükör

2. Tál

Kihajló, árkolt peremü, alacsony talpgyűrüs. Szürke festett, belül koncentrikus körök közötti, ferde bevágásokkal, legbelül bepecsételt, kétszer ismétlődő díszítéssel. Á: $20,5 \mathrm{~cm}$. Fá: $9 \mathrm{~cm}$. M: $4 \mathrm{~cm}$. Ltsz.: R.94.58.1. (X. t. 1. és 8. ábra.).

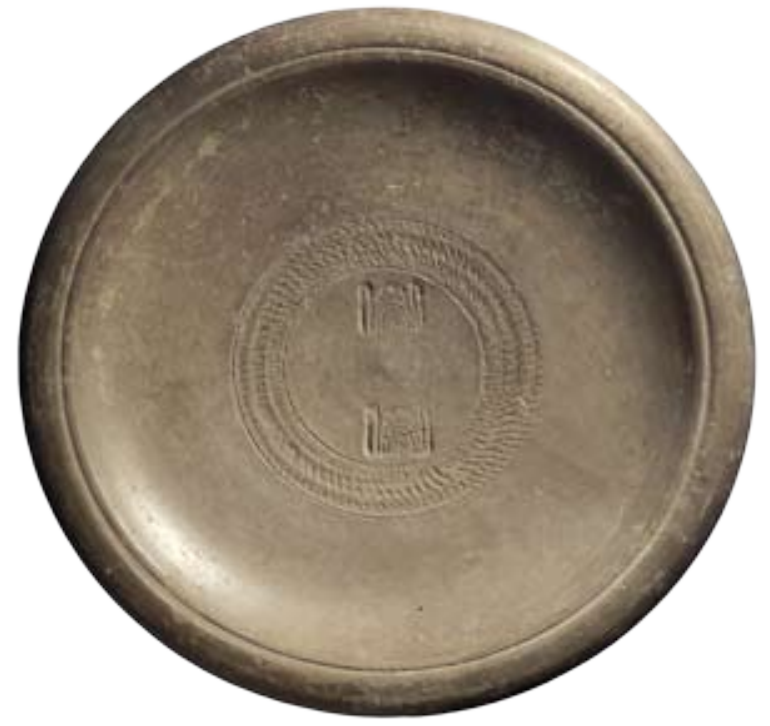

8. ábra. Bepecsétel tál Szóládról

3. Pohár

Kihajló peremü bögre, vállán árkolások futnak körbe. A peremén lévő kisebb hiánytól eltekintve ép, világosszürke foltos barna. Szá: $6,5 \mathrm{~cm}$. Fá: 3,2 cm. M: 8,5 cm. Ltsz.: R.94.58.3. (IX. t. 2.).

181 RRM A. 6603. 


\section{Pohár}

Kihajló peremü bögre, vállán árkolások futnak körbe. Oldala, egy helyen benyomott, de ez nem díszítés, hanem a készítésekor keletkezett, akárcsak az edénytestre tapadt kerámiadarab. Ép, világosszürke. Szá: $8,8 \mathrm{~cm}$. Fá: 4,4 cm. M: $11,8 \mathrm{~cm}$. Ltsz.: R.94.58.2. (IX. t. 3.).

5. Pohár oldaltöredékei

Hasonló edény két oldaltöredéke. Vállán árkolások futnak körbe, világosszürke. H: 5,7 és $5,2 \mathrm{~cm}$. Sz: 5,2 és 4,8 cm. Fv: 0,4 cm. Ltsz.: R.94.58.4. (IX. t. 4.).

6. Oldaltöredékek

Nagyobb edény (fazék?) két oldaltöredéke, az egyik darabon éles válltöréssel. Kaviccsal sürün soványított, világosszürke. H: 6,7 és $12,5 \mathrm{~cm}$. Sz: 7,2 és 7,5 cm. Fv: 0,5 cm. Ltsz.: R.94.58.5. (IX. t. 5.).

A bronztükör az 1. és 2 . századra keltezhető. ${ }^{182} A$ poharak párhuzamait az 1-2. század fordulójára datált halomsírokban találjuk meg. ${ }^{183}$ Egy harmadik pohárhoz tartozott a két oldaltöredék, két további edénytöredék valószínủleg fazék darabja volt. A tál bepecsételt díszítése egyedi, függőleges elválasztó tagokkal kihangsúlyozott tojásfüzérre emlékeztet. Az ívelt idomok megjelenítése talán a tojássor félreértésén alapul, a motívum Augustustól Septimius Severusig ismert. ${ }^{184}$ A fentiek alapján a temető leletei a 2 . századra tehetőek.

\section{Szőlősgyörök - Homokbánya}

Csontvázas, bronzedényekben gazdag sírlelet kerül elő a homokbányából. ${ }^{185} \mathrm{~A}$ lelőhelyen több ízben volt leletmentés, melynek során telepleletek kerültek elö, de újabb sír nem. ${ }^{186}$

\section{Tab - Dózsa György utca}

Csizmadia Tibor kertjében csontvázas sírlelet került elö. A csontvázrészeket és a leleteket a rendőrség gyűjtötte össze és adta át a múzeumnak. ${ }^{187} \mathrm{~A}$ sírból, a végtagcsontok hossza alapján, egy 13-14 éves korú gyermek jó megtartású csontváza került elő, amelyből azonban a lábszárak és a lábfejek csontjai hiányoztak. Gyermekkorúak esetében a nem meghatározása még nem lehetséges. A csontokon kialakult néhány kóros elváltozás kisfokú táplálkozási hiányosságot jelez.

\section{Füles bögre}

Kihajló peremü, alacsony talpgyürüs edény. Finoman iszapolt, kaviccsal sürün soványított. Ép, szürke. Szá: $6,8 \mathrm{~cm}$. Tá: $3,5 \mathrm{~cm}$. M: $9,1 \mathrm{~cm}$. Ltsz.: R.225.1/1.1. (IX. t. 7.).

2. Vaskés

Nagyméretű vaskés, négyzet keresztmetszetű, elvékonyodó tüskével. A pengeél töredezett. H: 24,6

182 Kelbert 2007, 207-209.

183 K. Palágyi - Nagy 2000, 122

184 Maróti 1997, 318. 23-34. motívum.

185 Horváth 1981. KÖH 34313. lelöhely.

186 Németh 1993. A későbbi helyszínelések tanúsága szerint, a lelöhelyet a homokbányászás teljesen elpusztította.

187 Költő László leletmentése 2004. A közlés jogának átengedését Költő Lászlónak ezúton is köszönöm. cm. Penge H: 14,2 cm. Penge Sz: $2,2 \mathrm{~cm}$. Ltsz.: R.225.1/1.2. (IX. t. 6.).

A bögre párhuzamait a ságvári és somogyszili temetőben találjuk meg. ${ }^{188}$ A 4 . századra jellemző forma. ${ }^{189} \mathrm{~A}$ vaskéshez hasonló tárgy a zengővárkonyi II. temető 7. sírjából került elő. ${ }^{190}$

\section{Tab - Videoton}

Római temetőt említ Magyar Kálmán, a leletek azonban kelta koriak. ${ }^{191}$

\section{Teleki - Homokbánya}

Római urnatemető került be a régészeti nyilvántartásba, ugyanakkor lelet nem ismeretes. ${ }^{192}$

\section{Visz - Körmendy birtok}

Téglasírokról történik említés, melléklet nem volt, kérdéses, hogy római koriak lehetettek-e. ${ }^{193}$

\section{Visz - Pap János udvara}

1935-ben, beomlott sírból, karperec, lánc és edény került elő, kérdéses, hogy római kori lehetett-e. ${ }^{194}$

\section{Vörs}

A falu határában, a temető közelében, ott, ahol a battyánpusztai Vörsi út a földhátat eléri, a 2. világháború során, lövészárok ásásakor, római temető került elő, a leletek megsemmisültek. A csontvázas sírok mellékletei között bronzfibulák, karkötők is voltak. ${ }^{195}$ Egy másik feljegyzés szerint, a sírok, melyekhez bronz- és vastárgyak is tartoztak, Balatonszentgyörgyön kerültek elő. ${ }^{196}$

\section{Zamárdi - Szamárdombi agyagbánya}

A Szamárdomb északkeleti lejtőjén, az elhagyott bányában, két, 3. századi sír került elő. ${ }^{197}$

\section{Zamárdi - Gépállomás}

Késő római temető. ${ }^{198} \mathrm{~A}$ temető területéről származó dörzstál töredék és 4 db késő római érme került, ajándékozás révén, a kaposvári múzeumba. A lelőhelyen, magtár építésekor, nem került elő újabb sír. ${ }^{199}$

188 Sz. Burger 1966, 115. Fig. 105. és Sz. Burger 1979, 55. Taf. 22.2. 189 Lányi 1972, 70.

190 Dombay 1957, 20-2-3. 15. kép. XI. t. 6. Dombay beosztásában a 3. csoportba tartozik. Uo. 273.

191 Magyar, 2005, 58. KÖH 49859. lelöhely.

192 KÖH 28897. lelöhely. A kaposvári múzeum adattárában nincs adat, a 2010. évi régészeti megfigyelés során régészeti lelet nem került elő. RRM A. 2791.

193 Kocztur 1964, 156.

194 Kocztur 1964, 156.

195 KBM A: 61.93.1. és RRM A. 6586. KÖH 49734 (Vörs III.) lelöhely 196 KBM A. 61.96 .4

197 Archaeologiai Értesítő 1957, 84. KÖH 50038. lelöhely.

198 Németh, 2000. KÖH 50097. lelöhely.

199 Németh Péter Gergely régészeti megfigyelése, 2016. RRM A. 9050 
A Somogy megyei római kori halomsíros temetkezések az 1. és a 2. század fordulóján indulnak, a legkésőbbi temetkezést a somogyjádi 1 . halomban találjuk, mely a 3 . század 3 . harmadára keltezhető. A nem halmos temetkezések az 1 . században indulnak, kevés korai temetöre van jelenleg adatunk. A korai temetők között találjuk Szólád-Majort, a 2. században indul a kapolyi temető. Szintén kevés adatunk van 3. századi temetkezésre. A legtöbb lelet a 4 . századra keltezhető, itt felvetődik az a lehetőség, hogy szántás során előkerült téglák hívják fel a figyelmet a temetkezésre és így ezek jobban megmaradtak. A korábban közölt Zamárdi-Gépállomás temetője már 5. századra is átnyúlik. Az 5. század 2. feléből származó lelet került ki egy ságvári sírból. A korai népvándorlás korba tartoznak az ordacsehi sírok. Bár sok régi adattal rendelkezünk, ezekben több bizonytalanság van, több esetben a temetők száma is kérdéses, így Büssü területéröl több római kori temetöröl is van adatunk, ezek, részben egy temetőtőre vonatkozhatnak. Ugyanez áll Szántód és Vörs esetére is. A lelöhelytérkép (XII. tábla) alapján a temetők eloszlása egyenetlen, kérdéses, hogy ennek történelmi okai vannak, vagy csak a kutatás hiányát jelzik. A múzeumba eljuttatott sírlelet esetén felmerül az, hogy nem minden tárgyat gyűjtöttek össze és több sír előkerülése esetén a mellékletek összekeveredhetnek.

A tanulmányban közzétett anyag kiindulási pont lehet, a további leletek közzététele mellett, újabb és teljes temetőfeltárások nagymértékben megváltoztathatják az eddigi ismereteinket.

\section{Irodalom}

BAKAY K. 1975: Kaposvár földjének őstörténete a legrégibb időktől a honfoglalásig. In: Kaposvár Várostörténeti Tanulmányok. Szerk.: Kanyar József.

BARKóczy L. 1988: Pannonische Glasfunde in Ungarn.

BARTUS D. 20063: Aranyfejü csont hajtük. Archaeologiai Értesítő 131: 193-203.

Sz. Burger A. 1966: The Late Roman Cemetery at Ságvár. Acta Archaeologica XVIII: 99-234.

BóNIs É. 1942: A császárkori edényművesség termékei Pannoniában. (A Tera Sigillátákon kívül) I. A korai császárkor anyaga. Dissertationes Pannonicae II. 20.

SZ. BURGER A. 1979: Der Spätrömische Gräberfeld von Somogyszil. Fontes Archaeologici Hungariae.

CSIZMADIA G. 1998: A kaposvári Rippl-Rónai Múzeum római kori üvegleletei. Somogyi Múzeumok Közleményei 13: 91-112.

CsizmAdiA G. - NÉmetH P. G. 2016: Római kori halomsírok Somogy megyében. A Kaposvári Rippl-Rónai Múzeum Közleményei 4: 117-166.

DÉVAI K. 2012: A kúpos testű pohárforma funkcionalitásának kérdéséhez. FilRKÁK II. Györ. 261-268

DombaY J. 1957: Későrómai temetők Baranyában. Janus Pannonius Múzeum Évkönyve 2: 181-330.

DRAVECZKY B. - SÁGI K. - TAKÁTS GY. 1964: A Somogy Megyei Múzeumok régészeti adattára. Somogyi Múzeum 2.

DRAVECZKY B. 1965: Felfedező ásóval Somogy megyében II. Somogyi Szemle 1965/2. 66-76.

DRAVECZKY B. 1970: Kaposvár régészeti múltja. Somogyi Szemle 1970/1: 13-18.

EÖRY B. 1999: Balatonberény múltja az őskortól a népvándorlás koráig. Helytörténeti füzetek. 1. füzet. Balatonberény, 1999.

R. FACsÁDY A. 2009: Aquincumi ékszerek. Az Aquincumi Múzeum gyűjtemény 1

FEHÉR B. - KovÁcs P. 2017: Római faragott kőemlékek Somogyvárról. Megjegyzések Somogy megye római kori felirataihoz. Studia Epigraphica Pannonica IX: 5-43.

GAÁLA. 1979: Késő római sírok Mözs- Kakasdombon. Szekszárdi Béri Balog Ádám Múzeum Évkönyve VIII-IX: 23-85.

GÁsPÁR D. 1986: Römische Kästchen aus Pannoonien. Anteus 15.
HERK M. 1985: Karád története.

Hontı Sz., Gallina Zs., Hajdú Á. D., Hornok P., Koós I., Mersdorf Zs., Molnár I., Németh P. G., PolgáR P., P. Szeőke J., SerLEGI G., SIPOS C. És SOMOGYI K. 2007: Régészeti kutatások az M7-es autópálya Somogy megyei szakaszán és a 67-es úton (2004-2005). Előzetes jelentés IV. Somogyi Múzeumok Közleményei 17: 7-70.

HoRVÁTH L. 1981: A szőlősgyöröki római kori sír. Communicationes Archeologicae Hungariae. 59-81.

KELBERT K. 2007: Római tükrök Savariában. Savaria 31: 171-261.

KocztuR É. 1964: Somogy megye Régészeti Leletkatesztere. Régészeti Füzetek II. 13

KolBACH B. 1903: A szóládi leletekröl. Archaeologiai Értesítő XXIII: 413-416.

KUZsıNSZKY B. 1920: A Balaton környékének archaelogiája. Budapest.

LACZKó D. 1912: Római telepnyomok és útirányok Veszprém megye déli felében. In: Baláca. Veszprém, 1912. 5-30.

LÁNYI V. 1972: Die spätantiken Gräberfelder von Pannonien. Acta Archaelogica XXIV: 53-213.

MAGYAR K. 1987: Babócsa középkori nemzetségi központjának régészeti és építészettörténeti kutatásáról (1979-1986). Müemlékvédelem 4: 237-246.

MAGYAR K. 1985: Fonyód története az őskortól a középkorig. In: Fonyód története, Kaposvár, 1985.

MAgYAR K. 2005: Tab régészeti emlékei. In: Tabi Kilátó 2004-2005: 53-69.

MAGYAR K. 2016: A fonyódi 150 éves présház (Homokbánya) és Sándor u. 26. területén lévő 10-11. századi temetők sírjainak leletmentése. A Kaposvári Rippl-Rónai Múzeum Közleményei 4: 181-201.

MARÓTI É. 1997: Római kori, pecsételt edénytöredékek KomáromEsztergom megyéböl (I.). Komárom-Esztergom Megyei Múzeumok Közleményei 5: 287-348.

MRÁV Zs. 2007: Díszpajzs, markolatgyűrüs kard és lándzsák egy budaörsi római kori kocsisírból. FiRKáK I. Fiatal római koros kutatók I. Konferenciakötete. 233-266

NAGY E. 1994: V. századi népvándorlás kori sírok Pécs- Málom lelőhelyen. Janus Pannonius Múzeum Évkönyve 38: 95-102.

NAGY M. 2004: Két késő római kori fegyveres sír az aquincumi canabae nyugati szélén. Budapest Régiségei XXXVIII: 231-315. 
NÁDoRFI G. 1992: Glasierte Keramik in den spätrömischen Gräberfelden Pannoniens. In: Glasierte Keramik in Pannonien. Székesfehérvár. 45-51.

NÉMETH P. G. 1993: Szőlösgyörök és környékének régészete az őskortól a honfoglalás koráig. In: Szőlősgyörök története 1993. 35-52.

NÉMETH P. G. 1996: Késő római sírlelet Csomáról. Somogyi Múzeumok Közleményei 12: 39-46.

NÉmetH P. G. 2000: Késő római temető Zamárdiban. Somogyi Múzeumok Közleményei 14: 29-39.

MELHÁRD GY. 1882: A somogyvármegyei régiségtár köréből. A Somogyvármegyei Régészeti s Történeti Társulat Évkönyve 1879-1881. Kaposvár, 1882.

OTTOMÁNYI K. 1990: Késő római házak Szakályban. Archaeologiai Értesítő 117: 161-188.

OTTOMÁNYI K. 1991: Késő római kerámia a leányfalui őrtoronyból. Studia Comitatensia 22: 5-144.

K. PALÁgyI S. - NAGY L. 2000: Római halomsírok a Dunántúlon. Veszprém.

PÁszTÓKAI - SzEŐKE J. 2012: Vasból készült szövőeszközök és textilmüvesség a 4. századi Dunántúlon. In: Petkes Zs. (szerk.) Hadak útján XX. Népvándorláskor Fiatal kutatóinak XX. Összejövetelének Konferenciakötete. Budapest, 2012.

V. PÉTERFI J., 1993: A Bátaszék - Kövesd pusztai késő római temető. Wosinsky Mór Múzeum Évkönyve XVIII: 47-168.

PRÖtTEl PH. M. 1988: Zur Chronologie der Zwiebelknopffibeln. Jahrbuch des Römisch-Germanischen Zentralmuseums 35: 347-372.
RUPNIK L. 2014: Római kori vasszerszámok Pannoniából. Doktori disszertáció. Doktori.btk.elte.hu/hist/rupniklaszlo/diss.pdf.

SALAMON Á. - BARKócZI L. 1971: Bestattungen von Csákvár aus dem Ende des 4. und dem Anfang des 5. Jahrhunderts. Alba Regia $\mathrm{XI}: 35-80$.

SCHMIDT W. 2000: Spätantike Gräberfelder in den Nordprovinzen des römischen Reiches und das Aufkommen christlichen Bestatttungsbrauchtums Tricciana (Ságvár) in der Provinz Valeria. Saalburg-Jahrbuch 50: 213-441.

SÁGı K. 1973: Római téglasír Balatonberényben és ókeresztény kapcsolatai. Somogyi Múzeumok Közleményei 1: 289-297.

SÁGI K. 1983: Szántódpuszta története a magyar államalapításig. Szántódi füzetek IV.

SÁGI K. 1989: Siófok története az őskortól a középkorig. Siófok. Várostörténeti tanulmányok. Szerk. Kanyar József. Kaposvár, 7-41.

SÁGI K. - CsÉBY G. 1990: Balatonszemesi régészeti emlékei. In. Szemes. Tanulmányok Balatonszemes múltjából és jelenéből. 59-84.

SÁGI K. - CsÉBY G. 1993: Régészeti és történeti emlékek. In. Szólád története. 51-85

TóTH E. 2009: Studia Valeriana. Az alsóhetényi és ságvári késő római erődök kutatásainak eredményei. Dombóvár, 2009.

TóTH E. 2011: A pannoniai késő római besimított kerámia eredetéről (carpok a Dunántúlon. Http://www.mimuzeum.ro/files/mimk3/ Toth Endre.pdf.

B. VÁGÓ E. - BóNAI I. 1976: Die Gräberfeleder von Intercisa I. Der Spätrömische Südostfriedhof. 


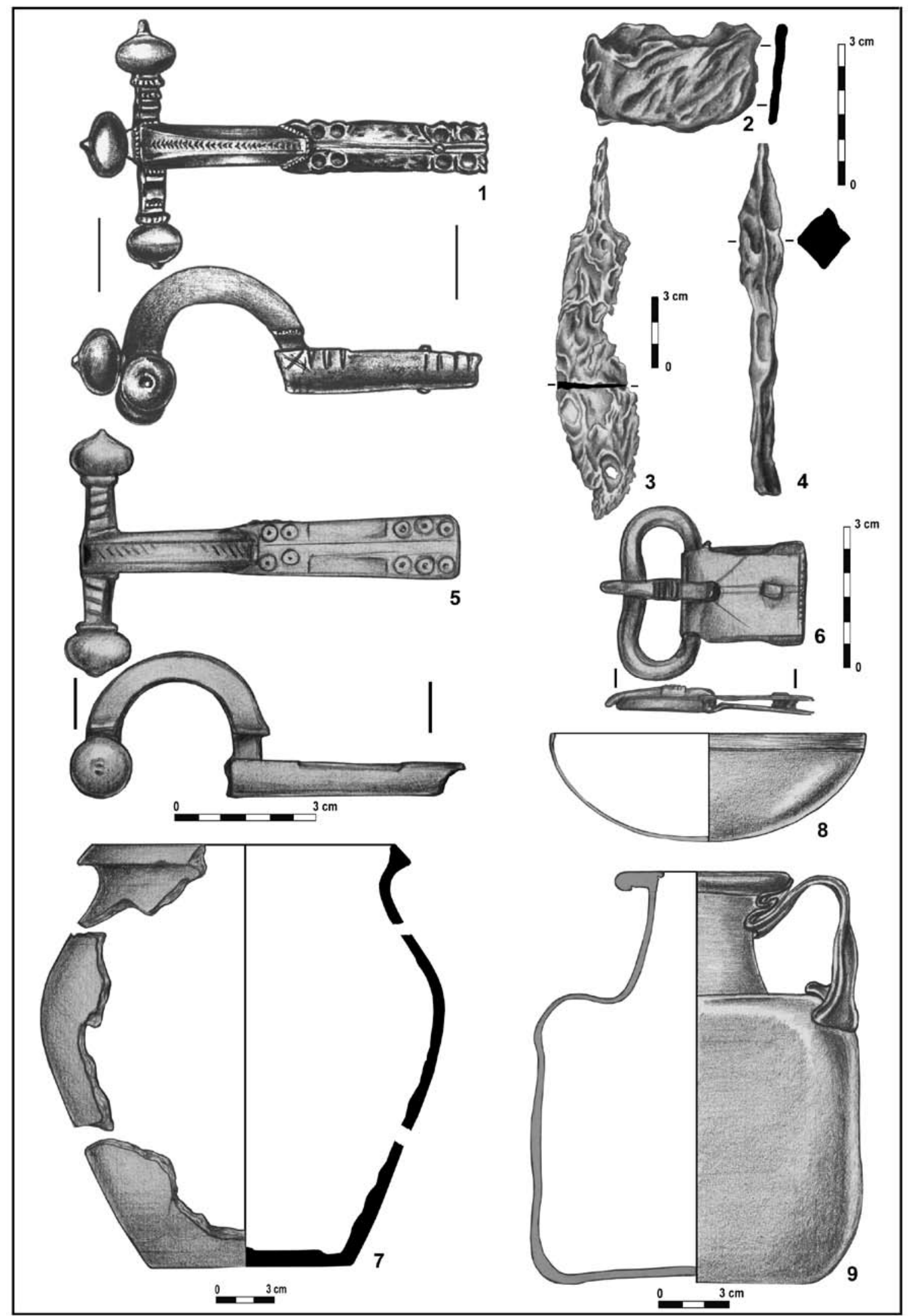

I. tábla. 1-6. Balatonlelle - Rádpuszta-Agyagbánya. 7. Balatonszabadi - Homokbánya. 8-9. Buzsák. 1-2., 4-6. M:1:1, 3., 7-9. M: 1:2 


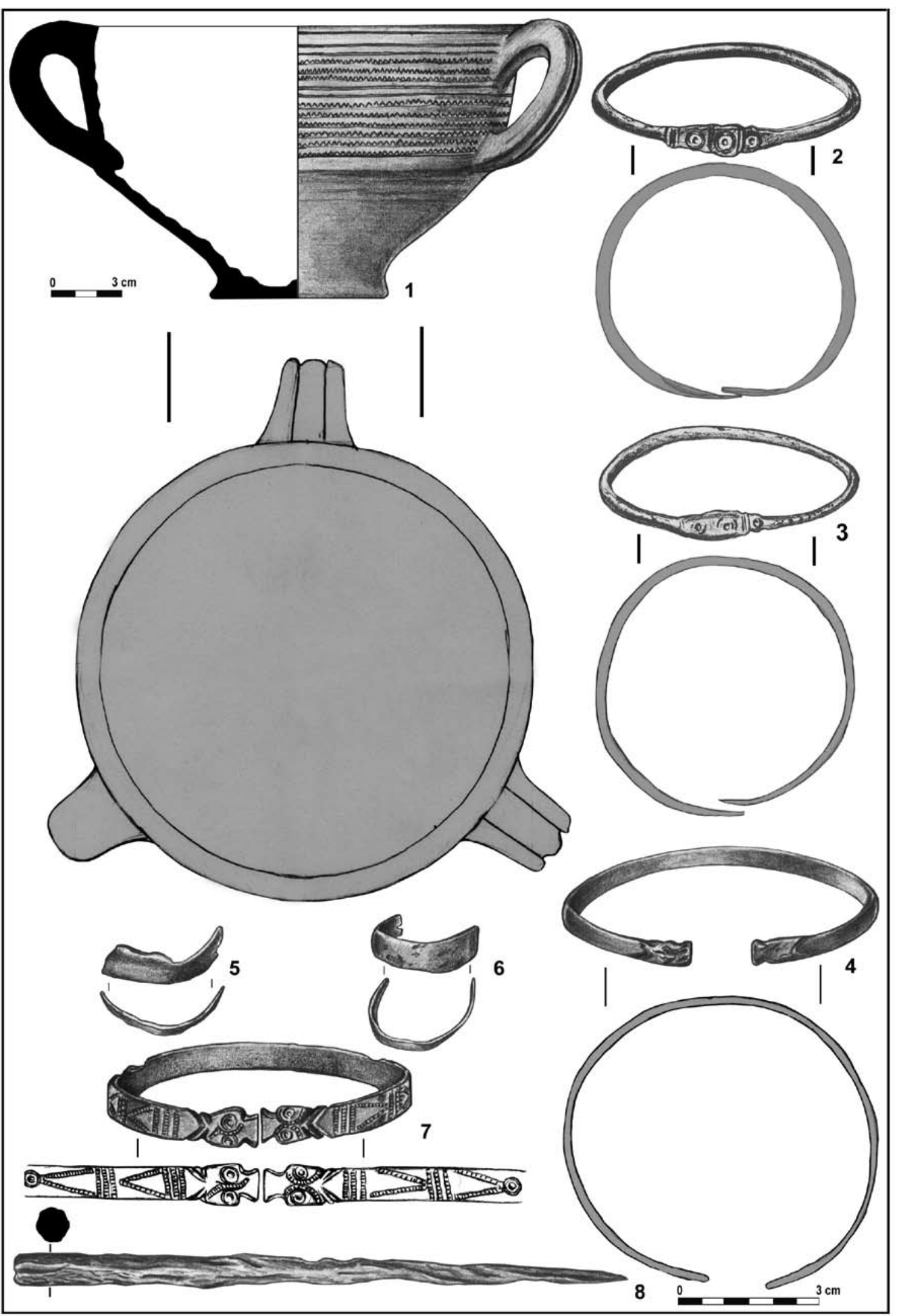

II. tábla. 1-3., 8. Bonnya. 4-7. Balatonszabadi-Siómaros.

1., 8. $M: 1: 2,2-7 . M: 1: 1$ 


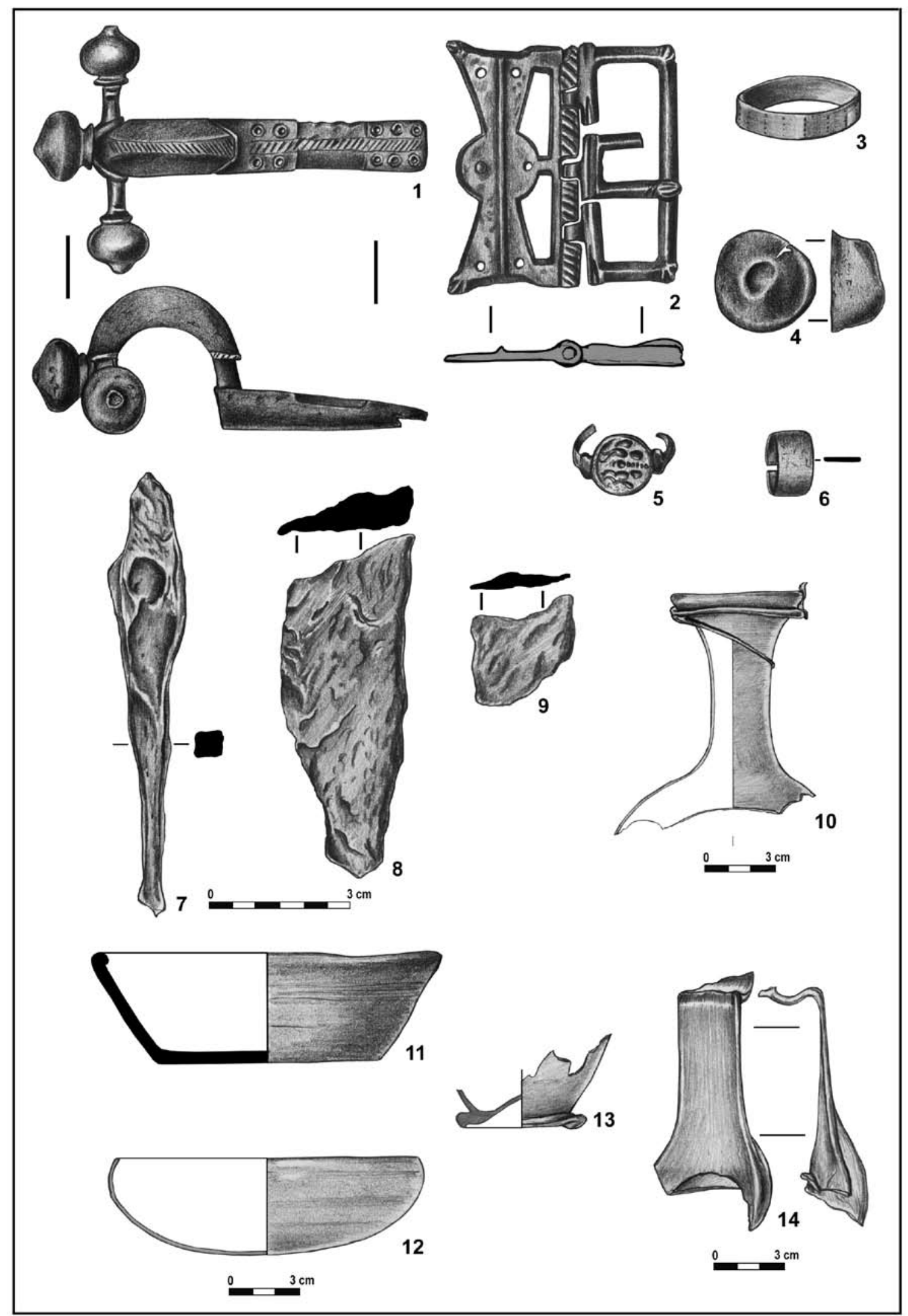

III. tábla. 1-9. Büssü - Halastói agyagbánya. 10-14. Igal - Homokbánya. 1-9. $M: 1: 1,10-14 . M: 1: 2$ 


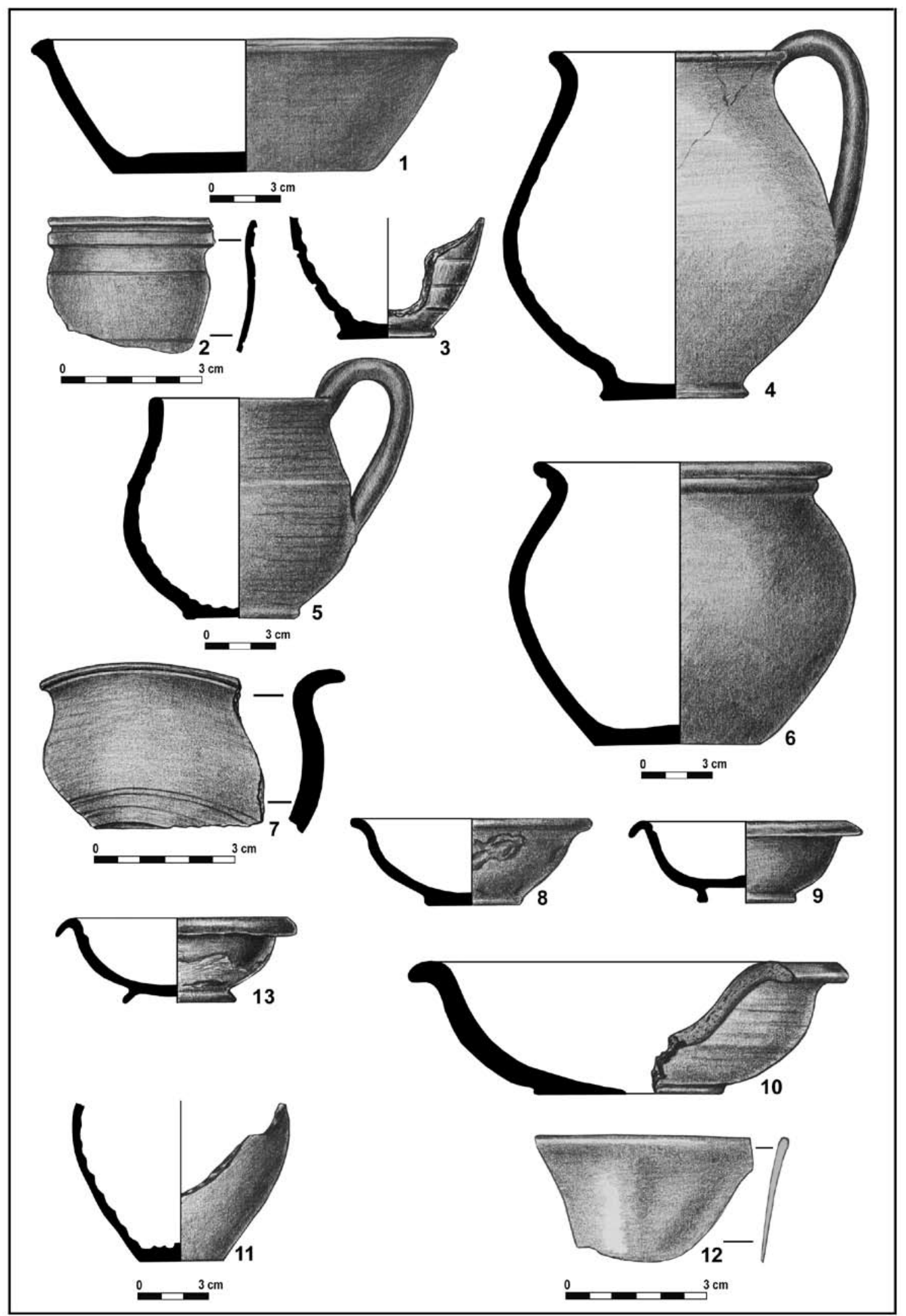

IV. tábla. Kapoly - Kapolypusztai elágazás.

1-11. M:1:2, 12. M:1:1 


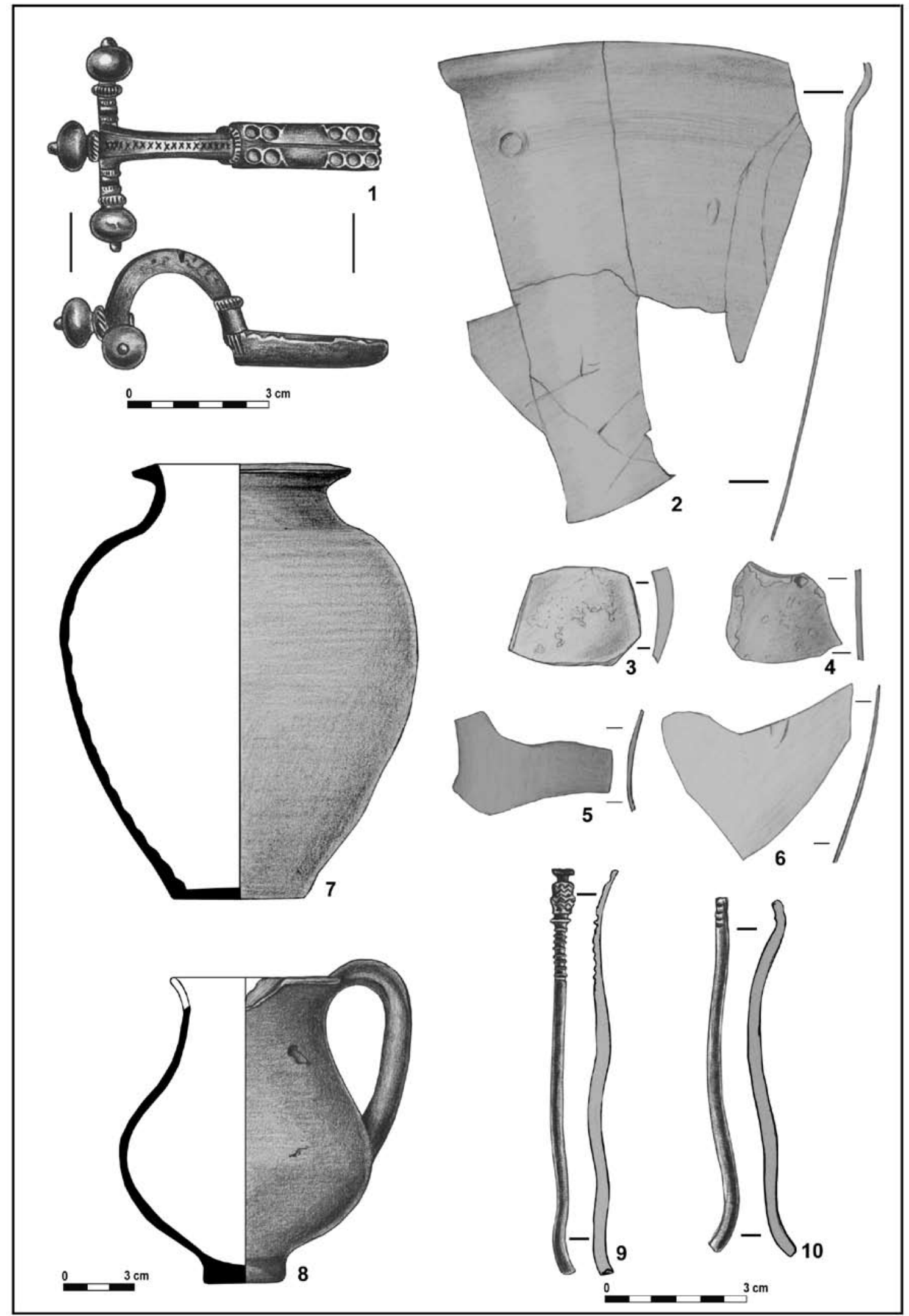

V. tábla. 1. és 7. Kapoly - Kapolypusztai elágazás. 2-6. Nagyberény - Füzfa-csárda. 8-10. Nagyberény. 1-6., 9-10. M:1:1, 7. M:1:3, 8. M:1:2 


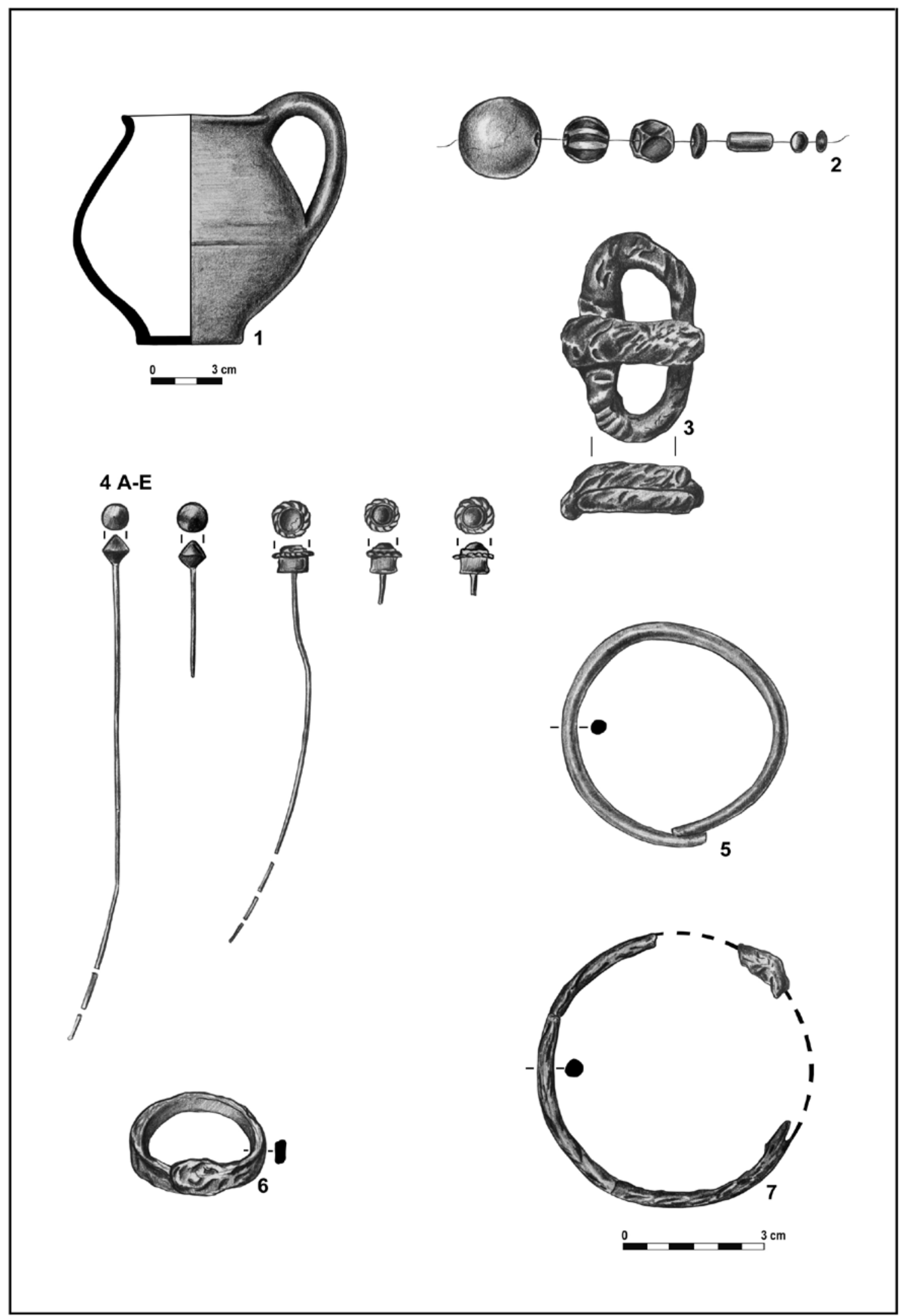

VI. tábla. 1. Nemesvid - Iskolaudvar. 2-3. Ordacsehi - Bugaszegi homokbánya. 4-7. Somogyszil - Csárdavölgyi-dülö. 1. M:1:2, 2. M:1,5:1, 3-7. M:1:1. 


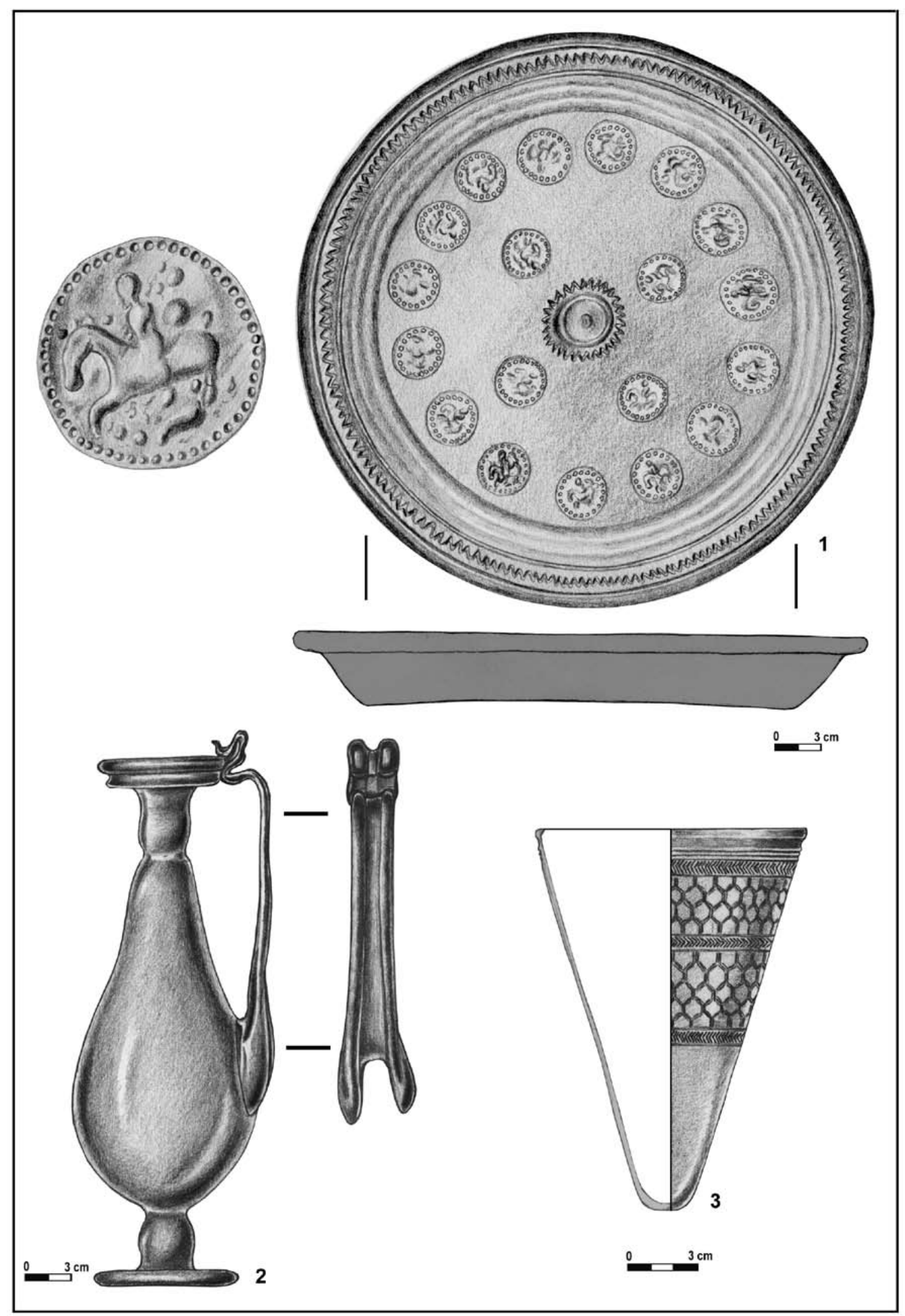

VII. tábla. Mosdós - Szölöhegy.

1-2. $M: 1: 3$, 3. $M: 1: 1: 2$ 


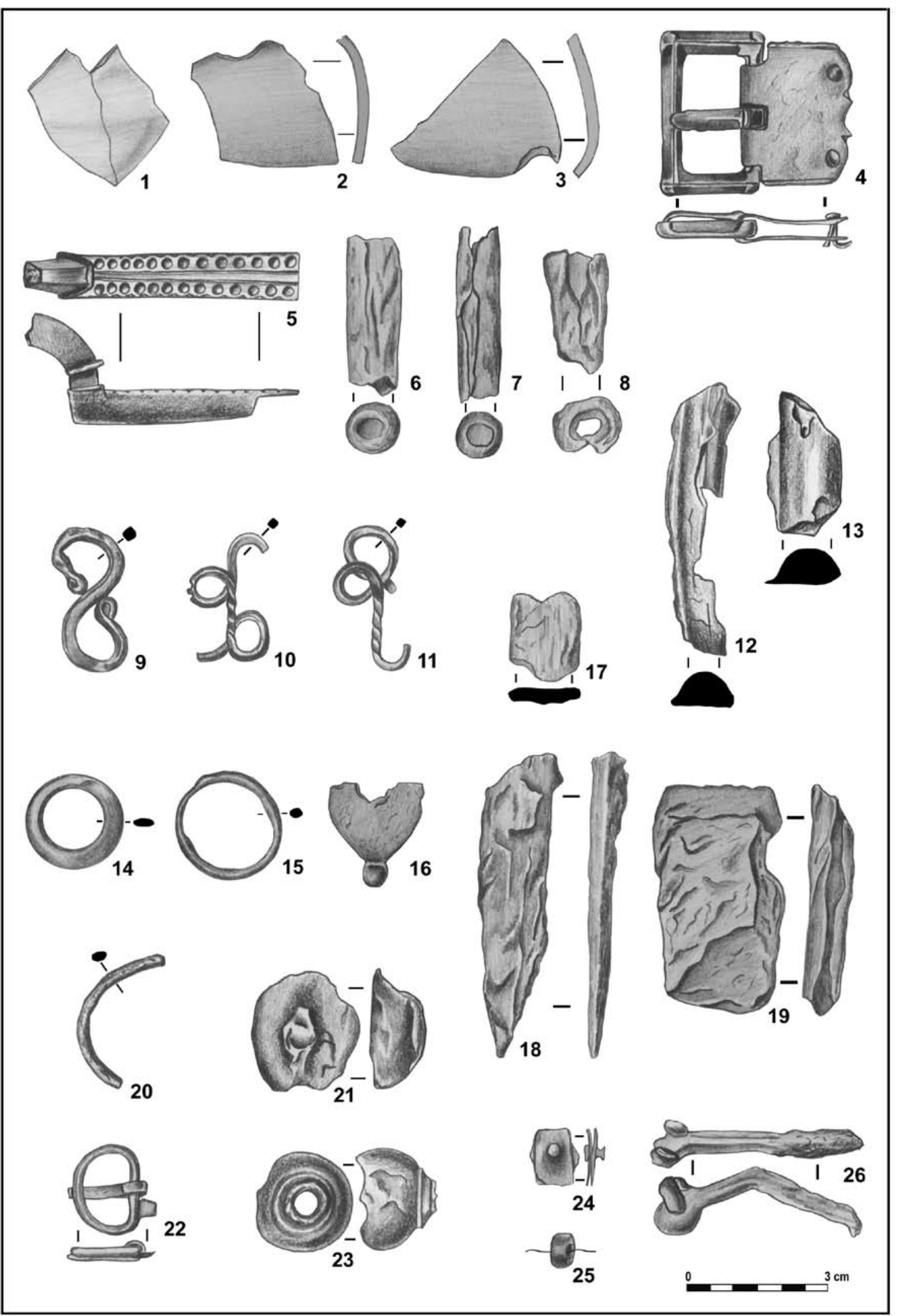

VIII. tábla. Ságvár - Tömlöchegy. M:1:1 


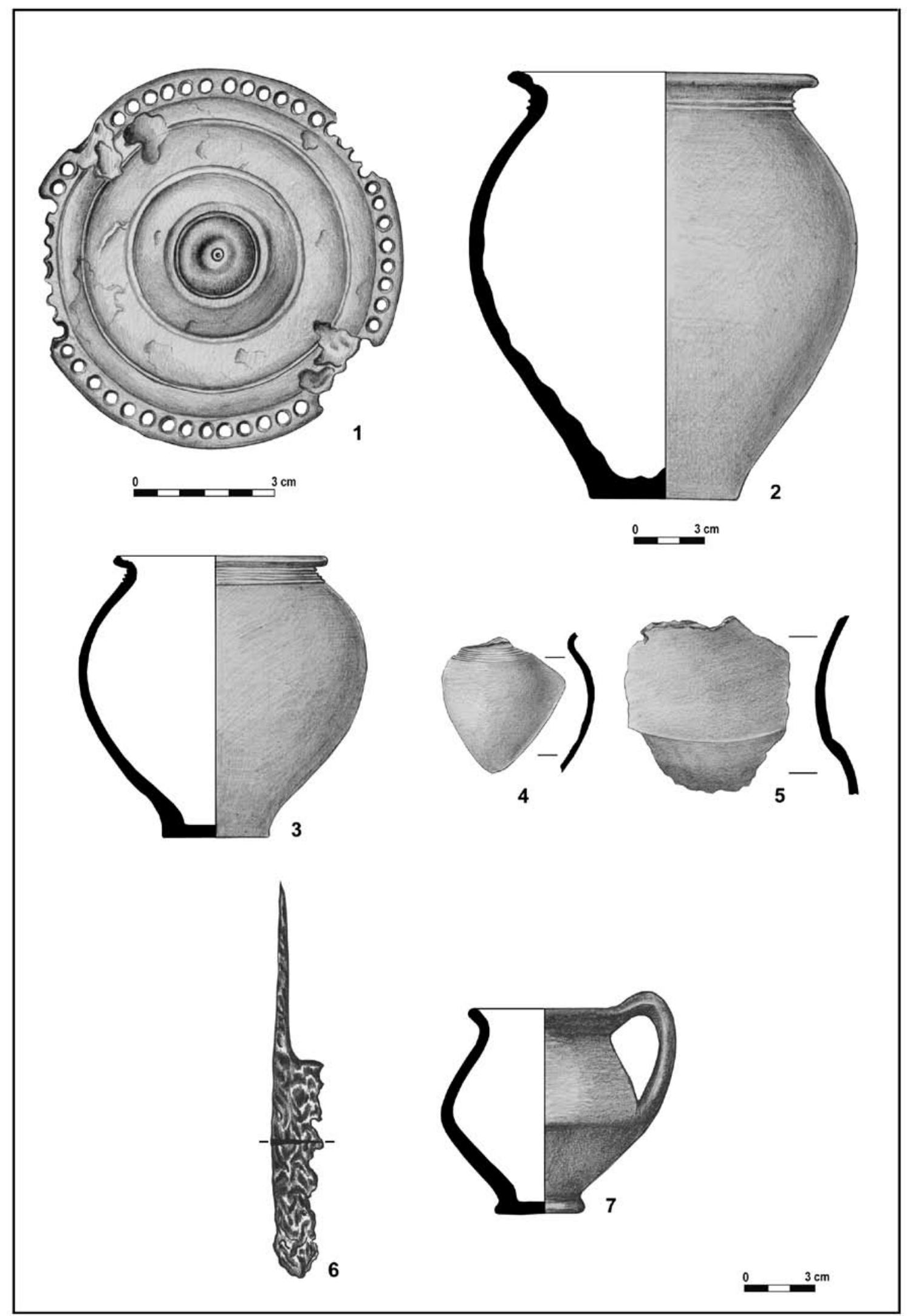

IX. tábla. 1-5. Szólád - Major. 6-7. Tab-Dózsa György utca.

1-2. M:1:1, 3-5. és 7. M:1:2, 6. M:1:3 


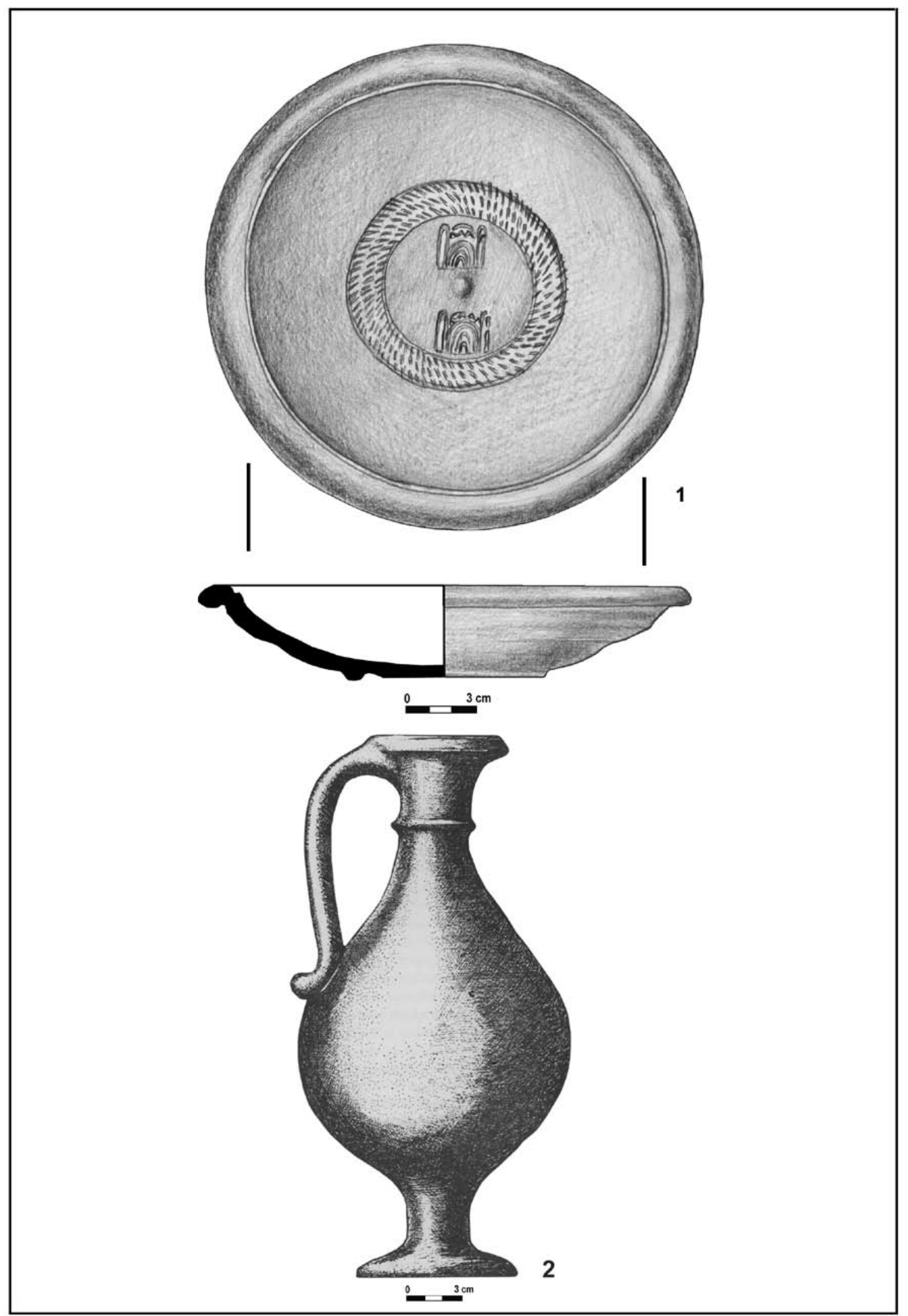

X. tábla. 1. Szólád - Major. 2. Szántód - Szántódpuszta. M:1:2. 2. Sági 1983, 19. rajz után 
m
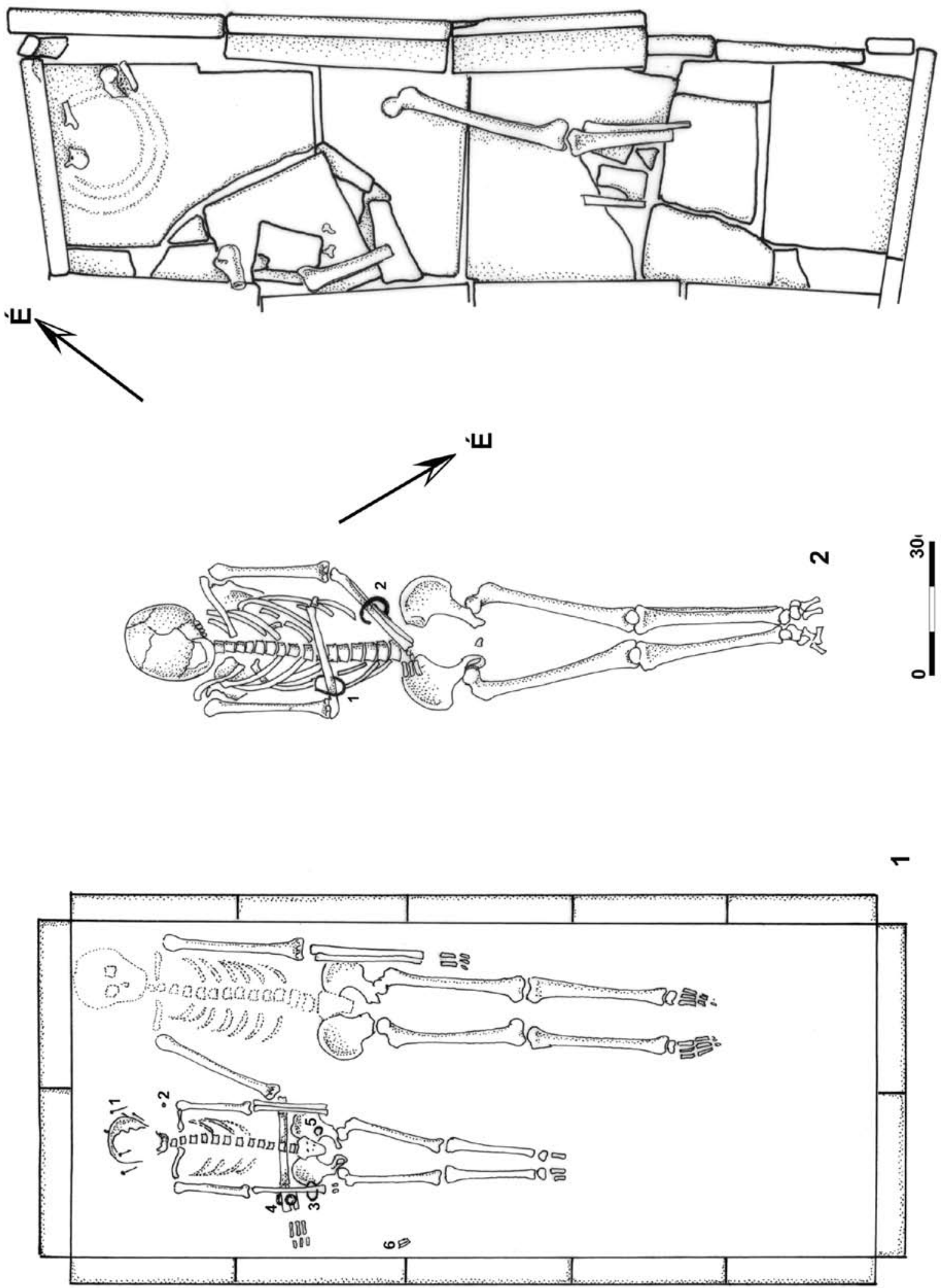

XI. tábla. 1. Somogyszil - Csárdavölgyi-dülö. 2. Nagyberki-Szalacska. 3. Nagyberény - Füzfa camping mellett 


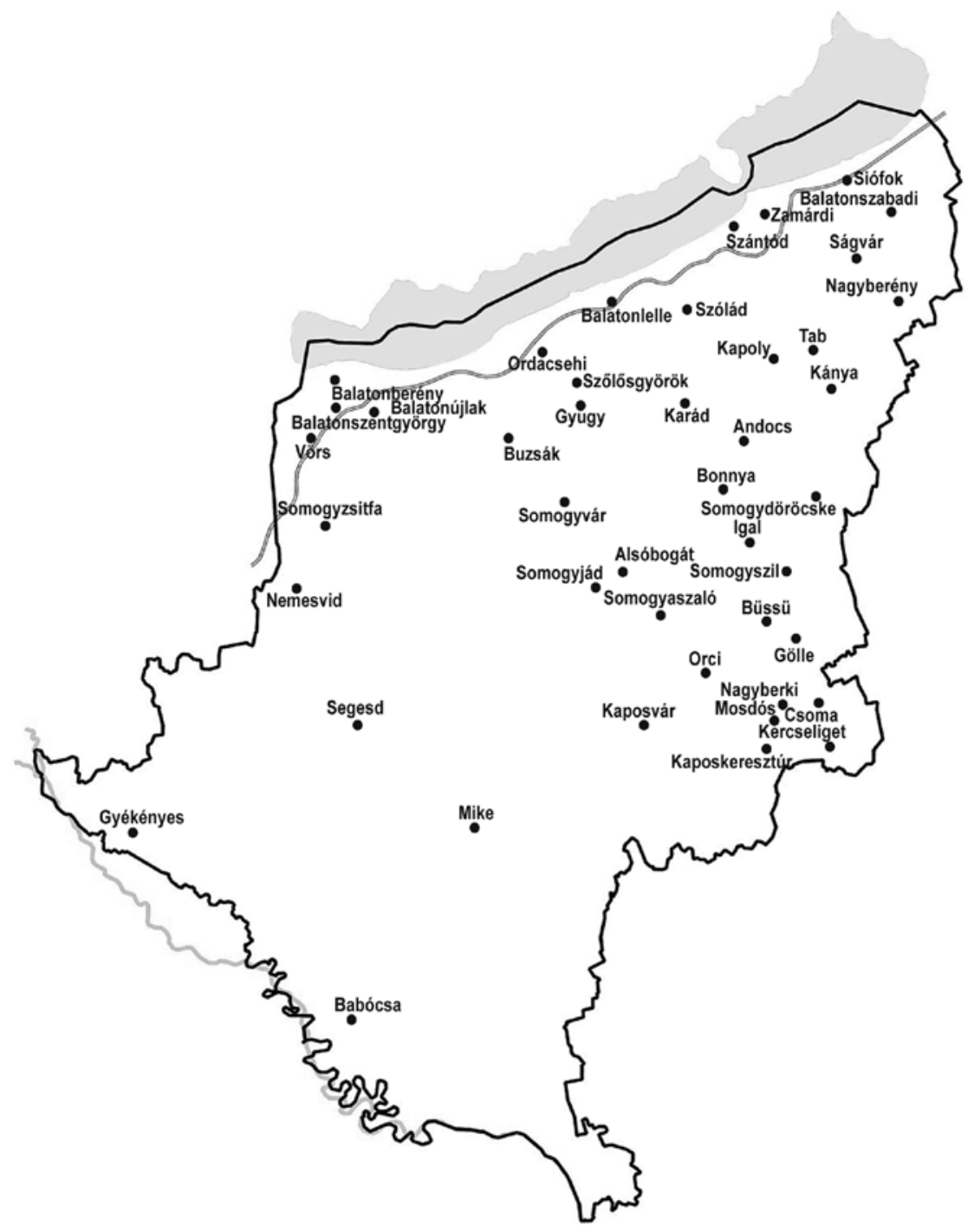

XII. tábla. Római kori temetők térképe

\title{
Roman Cemeteries in County Somogy
}

\author{
PÉTER GERGELY NÉMETH
}

Roman Age barrow burials in co. Somogy begin at the turn of the $1^{\text {st }}$ and $2^{\text {nd }}$ centuries. The latest one was found in Barrow 1 at Somogyjád, dated to the last third of the $3^{\text {rd }}$ century. Non-barrow burials begin in the $1^{\text {st }}$ century with only scarce data for early cemeteries including Szólád-Major and Kapoly beginning in the $2^{\text {nd }}$ century. $3^{\text {rd }}$ century burials are also very poorly supported by data. Most cemeteries are dated to the $4^{\text {th }}$ century, given that the bricks uncovered during field cultivation draw attention to the burial, leaving a better chance to survive. The cemetery at Zamárdi-Gépállomás published earlier reaches even over to the $5^{\text {th }}$ century. A grave at Ságvár yielded a find from the second half of the $5^{\text {th }}$ century. The graves at Ordacsehi belong to the Migration Period. Though a lot of old data are available, they contain several uncertain factors, even the number of cemeteries is questionable in some cases. Thus the data we have about several cemeteries at Büssü may partly refer to one. The same applies to Szántód and Vörs, where the site map (Table XII) shows an uneven distribution of the cemeteries. It is uncertain whether it is the result of historical reasons or simply a lack of research. In the case of the grave finds delivered to the museum the issue arises that not all the objects may have been collected and if several graves had been uncovered, the grave goods may have been mixed up. The material published in the study may be a starting point, while new and full cemetery excavations in addition to the publication of further finds should bring about a significant change in what we know so far. 